A N N A L E S

UNIVERSITATIS M A R I A E C URIE-SKŁODOW S K A

LUBLIN - POLONIA

VOL. XXXIII, 2

SECTIO J

2020

Uniwersytet Wrocławski. Wydział Nauk Historycznych i Pedagogicznych

\title{
DANUTA BORECKA-BIERNAT
}

ORCID: 0000-0003-1401-9821

danuta.borecka-biernat@uwr.edu.pl

\section{Ocena poznawcza konfliktu i emocjonalny wymiar strategii radzenia sobie młodzieży w sytuacji konfliktu społecznego}

Cognitive Evaluation of Conflict and Emotional Dimension of Youths' Strategies for Coping with Social Conflict

Propozycja CYTOWANIA: Borecka-Biernat, D. (2020). Ocena poznawcza konfliktu i emocjonalny wymiar strategii radzenia sobie młodzieży w sytuacji konfliktu społecznego. Annales Universitatis Mariae Curie-Skłodowska. Sectio J, Paedagogia-Psychologia, 33(2), 179-206. DOI: http://dx.doi. org/10.17951/j.2020.33.2.179-206.

\section{STRESZCZENIE}

Celem badań było poznanie zależności pomiędzy oceną poznawczą konfliktu i emocjonalnym odzwierciedleniem znaczenia tej sytuacji oraz przebiegu własnych działań a występowaniem destruktywnej (agresji, uniku, uległości) i konstruktywnej (zadaniowej) strategii radzenia sobie młodzieży w sytuacji konfliktu społecznego. W badaniach posłużono się Kwestionariuszem Oceny Stresu (KOS) Włodarczyk i Wrześniewskiego, Trójczynnikowym Inwentarzem Stanów i Cech Osobowości (TISCO) Spielbergera i Wrześniewskiego oraz Kwestionariuszem do badania strategii radzenia sobie młodzieży w sytuacji konfliktu społecznego (KSMK) Boreckiej-Biernat. Badania empiryczne przeprowadzono w szkołach gimnazjalnych. Objęły one 893 adolescentów (468 dziewczynek i 425 chłopców) w wieku 13-15 lat. Analiza wyników badań wskazuje, że ocena sytuacji konfliktu w kategorii zagrożenia lub krzywdy/straty oraz reagowanie na nią gniewem lub lękiem współwystępuje z tendencją do destruktywnego reagowania młodzieży na konflikt. Ponadto badania wykazały, że adolescent, który znalazł się w sytuacji konfliktu, nieoceniający tej sytuacji w kategorii krzywda/strata i reagujący na nią ciekawością, skorzysta ze strategii konstruktywnej, aby poradzić sobie z tą sytuacją.

Słowa kluczowe: młodzież; ocena poznawcza; reakcje emocjonalne; strategia radzenia sobie; sytuacja konfliktu społecznego 


\section{WPROWADZENIE}

Sytuacje trudne nie są w życiu człowieka czymś wyjątkowym. Przeciwnie, towarzyszą mu od wczesnego dzieciństwa, nie jest więc obojętna wiedza na temat działań podejmowanych przez jednostkę w celu radzenia sobie w sytuacjach trudnych oraz warunkujących je czynników. W psychologii pojęcie „sytuacja trudna" ściśle się wiąże z czynnościami, jakie jednostka wykonuje w ramach regulacji swego stosunku z otoczeniem (Tomaszewski, 1984). W takich sytuacjach czynności jednostki napotykają na przeszkody, ulegają zahamowaniu, a niekiedy osiągnięcie zamierzonego celu zostaje udaremnione. Sytuacje trudne nie stanowią jednolitej klasy sytuacji, lecz są grupą wewnętrznie zróżnicowaną. Ważną grupą sytuacji trudnych są trudne sytuacje społeczne, czyli sytuacje, które stwarzają zagrożenie dla cenionych przez człowieka wartości, zaspokojenia jego potrzeb i realizacji dążeń natury społecznej (Tyszkowa, 1986). Wśród trudnych sytuacji typu społecznej interakcji wyodrębnia się sytuacje konfliktu społecznego, w których dążenia jednostki są sprzeczne lub niezgodne $\mathrm{z}$ dążeniami innych ludzi i zagrożona jest realizacja jej własnych dążeń. Sytuacja konfliktu z drugim człowiekiem uchodzi za jedną z podstawowych trudnych sytuacji społecznych w życiu każdego człowieka. Jest nieodłącznym elementem życia. Występuje powszechnie i nie da się jej w dłuższej perspektywie uniknąć. Wydaje się słuszne stwierdzenie, że konflikt jest wpisany w byt i naturę człowieka. Słowo „konflikt” wywodzi się od łacińskiego rzeczownika confligere, conflicatio, oznaczającego wpadnięcie na siebie, spór, dyskusję, walkę lub zderzenie dwóch czy więcej procesów, sił właściwych istotom żywym. Konflikty powstają w toku codziennych kontaktów między jednostkami lub między jednostką a grupą w wyniku występujących sprzeczności, niezgodności czy rozbieżności dotyczących celów, do realizacji których dążą strony konfliktu, a także poglądów, postaw, interesów i wartości czy motywów dążeń i pragnień (Balawajder, 2010). „Wpadnięcie na siebie” może zapoczątkować walkę. Wielu ludziom konflikt niesłusznie kojarzy się wyłącznie z bezpośrednią agresją fizyczną i/lub werbalną oraz towarzyszącą mu wrogością, powiększającą istnienie sprzeczności. Ten typ konfliktu nasycony jest emocjami negatywnymi. Większość zjawisk, które można określić jako konflikty, przybiera stosunkowo łagodne formy, np. krótkiej sprzeczki, dyskusji czy debaty (Olubiński, 1992).

W życiu nastolatków częste są trudne sytuacje społecznej interakcji zawierające element zagrożenia poczucia bezpieczeństwa, realizacji dążeń czy osiągnięcia celu (zaspokojenia potrzeb). Młodzi ludzie każdego dnia doświadczają różnorodnych problemów dotyczących szkoły, kolegów i domu rodzinnego. Rezultaty badań (zob. m.in. Jaworski, 2000; Lohman, Jarvis, 2000; Guszkowska, Gorący, Rychta-Siedlecka, 2001; Różańska-Kowal, 2004; Polak, 2010; Gurba, 2013; Domińska-Werbel, 2014) wykazały, że młodzież w okresie adolescencji najczęściej uważała konflikt z nauczycielem, sprzeczki z kolegami ze szkoły i z sympatią oraz 
kłótnie z rodzicami i innymi członkami rodziny za najważniejsze źródło osobistego zagrożenia, przykrych przeżyć i silnego odczuwania stresu.

Najbardziej kontrowersyjnymi sytuacjami w układzie uczeń - nauczyciel są oceny szkolne, nietaktowne zachowanie nauczyciela oraz władczy nacisk i sztywność jego wymagań. Warto zaznaczyć, że konflikt ucznia z nauczycielem jest sytuacją trudną dla ucznia, a mało znaczącą dla nauczyciela, który najczęściej go nie dostrzega lub go lekceważy. W miarę pobytu ucznia w szkole zwiększa się jednak częstotliwość występowania zatargów między uczniem a nauczycielem.

Z kolei konflikty rówieśnicze, mimo silnego ładunku emocjonalnego, są krótkotrwałe, przy jednoczesnym zmniejszaniu się częstotliwości zatargów w miarę pobytu ucznia w szkole. Główne ich powody to zaczepki, wyśmiewanie, niesłuszne posądzenia, obmowa, zdrada, niedyskrecja czy brak kultury w zachowaniu oraz rywalizacja o stopnie czy powodzenie u płci przeciwnej, władza nad klasą i prestiż sportowy.

Konflikty z rodzicami stanowią ważne źródło napięć w miarę dorastania. W związku ze zmianą stosunku dorastającego dziecka do rodziców, na skutek wyostrzonego krytycyzmu, pojawia się kryzys autorytetu rodziców oraz konflikty z nimi. Nieporozumienia z matką, ojcem i innymi członkami rodziny występują w 55-65\% populacji uczniów w wieku dorastania, przy czym bardziej konfliktowi są chłopcy niż dziewczęta (Matusewicz, 1997). Wiele tych konfliktów dotyczy codziennych sytuacji - różnic w opiniach, gustach (np. w sprawach związanych z ubiorem, muzyką, spędzaniem czasu wolnego). Mamy tu do czynienia ze ścieraniem się narastającej u młodych potrzeby samodzielności z ustanowionymi przez rodziców normami, nakazami i zakazami oraz z tendencjami do kontrolowania, nadzorowania życia i postępowania zbliżających się do dorosłości dzieci. Rodzice, pragnąc doskonałości swojego dziecka i marząc, by dziecko osiągnęło te cele w życiu, których nie udało im się spełnić, nakładają na nie duży ciężar obowiązków i oczekiwań, co jest próbą wymuszenia realizacji obowiązków rodzinnych.

Adolescencja jest okresem, w którym młodzież przeżywa różne, często ze sobą sprzeczne dążenia i musi radzić sobie z kierowanymi wobec siebie niespójnymi oczekiwaniami społecznymi. Sytuacja trudna pobudza młodego człowieka do aktywności ukierunkowanej na odzyskanie równowagi między wymaganiami a możliwościami i/lub poprawę stanu emocjonalnego. Aktywność, którą podejmuje w złożonych okolicznościach, rozpatruje się w konkretnym kontekście sytuacyjnym jako strategię radzenia sobie w aktualnej sytuacji trudnej (HeszenNiejodek, 2002). Liczne badania i nawet zwykłe obserwacje wskazują, że dorastająca młodzież dysponuje niemałym repertuarem strategii radzenia sobie w trudnych sytuacjach społecznych, m.in. w sytuacji konfliktu społecznego. Znajduje się wśród nich strategia destruktywnego i konstruktywnego radzenia sobie w sytuacji konfliktu społecznego (Gawryś, 2002; Kłusek-Wojciszke, 2009; Borecka-Biernat, 2012; Domińska-Werbel, 2014). Strategia destruktywna w sytuacji konfliktu 
społecznego $\mathrm{w}$ formie zachowań obronnych nie jest ukierunkowana na rozwiązanie i przezwyciężenie sytuacji konfliktu, ma ograniczoną wartość z punktu widzenia rozwiązania konfliktu, pozwala człowiekowi jedynie obniżyć przykre napięcie emocjonalne. Natomiast cel, który człowiek sobie początkowo stawiał, zostaje zastąpiony innym - osiągnięciem dobrego samopoczucia. Dokonuje się to przez: agresję, przybierającą formę inicjowanego ataku werbalnego i/lub fizycznego skierowanego przeciw określonym osobom, wyrządzającego szkody w fizycznym, psychicznym i społecznym dobrostanie innych osób (tj. wywołującego ból, cierpienie, destrukcję prowadzącą do utraty cenionych wartości); unikanie konfrontacji z sytuacją konfliktu, polegające zarówno na odraczaniu działań i aktywności, zwlekaniu z podejmowaniem wysiłków zaradczych w kierunku rozwiązania konfliktu, podjęciu dodatkowych czynności angażujących uwagę i odwracających ją od sytuacji konfliktu (oglądanie telewizji, słuchanie muzyki, objadanie się, uprawianie sportu, gra na komputerze, serfowanie po internecie), jak i na poszukiwaniu kontaktu z innymi ludźmi; uleganie, polegające na rezygnowaniu z dobra własnego, obrony własnych interesów czy zaniechaniu realizacji własnych celów/zamierzeń w sytuacji konfliktu na rzecz interesów partnera, jego potrzeb oraz przystosowaniu się do jego poglądów, sposobów działania i zachowaniu z nim pozytywnej relacji.

Strategia konstruktywna w formie zadaniowego zmagania się z sytuacją konfliktu społecznego zmierza do rozwiązania i przezwyciężenia konfliktu. Mieszczą się tu próby dokonywania zmian w obrębie własnego działania poprzez podjęcie wysiłku porozumienia się z partnerem w celu znalezienia wspólnego rozwiązania spornych kwestii. Zakłada ona asertywne liczenie się z celami i potrzebami uczestnika sporu, gdzie nic nie dzieje się kosztem drugiej strony ani kosztem własnych celów i interesów. Podstawową cechą konstruktywnej strategii radzenia sobie w sytuacji konfliktu społecznego jest to, że struktura celu zostaje utrzymana, zmienia się natomiast organizacja czynności umożliwiających jego osiągnięcie. Strategię konstruktywnego radzenia sobie w sytuacji konfliktu cechuje więc elastyczność, ponieważ jeden i ten sam cel może być osiągnięty przy użyciu różnych sposobów postępowania. Jak widać, podstawową cechą tej strategii jest jej duża skuteczność dzięki osiąganiu zamierzonych bądź równoważnych celów mimo sytuacji konfliktu.

Dotychczasowe wyniki badań wskazują, że młodzi ludzie w wieku dorastania podejmują walkę o status człowieka dorosłego, uzyskują więcej wolności i niezależności odnośnie do podejmowanych przez siebie decyzji dotyczących różnych obszarów zachowania oraz rozwijają nowe formy wyrażania siebie, co zwiększa prawdopodobieństwo pojawienia się konfliktów w relacjach z nauczycielami, rówieśnikami i rodzicami (Czerwińska-Jasiewicz, 2003). Dyscyplina ze strony szkoły i rodziców, zbyt mała niezależność młodzieży i brak zrozumienia dla jej zainteresowań prowadzą do sprzeczek, kłótni i buntów. Niektórzy młodzi ludzie 
w obliczu sporu w szkole, w relacjach z rówieśnikami czy w domu rodzinnym przyjmują strategię destruktywną w postaci agresywnego reagowania na konflikt, unikania aktywnego działania w obliczu konfliktu przez angażowanie się w inne bezstresowe formy aktywności czy ulegania konfliktowi (Frączek, 2003; Różańska-Kowal, 2004; Lachowska, 2010; Gurba, 2013). Są jednak i tacy młodzi ludzie, którzy dobrze radzą sobie w sytuacji konfliktu społecznego, traktują go jako wyzwanie dla siebie, co skłania ich do mobilizacji swoich zasobów w celu pokonania przeszkód uniemożliwiających realizację potrzeb (Osterman i in., 1997; Donaldson, Prinstein, Danovsky, Spirito, 2000; Kobus, Reyes, 2000; Tezer, Demir; 2001; Eschenbeck, Kohlmann, Lohaus, 2007).

Rezultaty badań i obserwacje wskazują na indywidualne zróżnicowanie reakcji na trudności i obronę przed nadmiernym napięciem emocjonalnym wśród młodych ludzi (Rostowska, 2001; Pisula, Sikora, 2008). Zdaniem Marii Tyszkowej (1986) w psychologicznym mechanizmie zachowania się człowieka w sytuacjach trudnych szczególną rolę odgrywają schematy (struktury) poznawcze osobowości, wyznaczające procesy spostrzegania sytuacji zewnętrznej, oraz emocjonalne odzwierciedlenie znaczenia tej sytuacji i przebiegu własnych działań. Schemat poznawczy jest reprezentacją pewnego fragmentu rzeczywistości, w aktywny (przetworzony) sposób odzwierciedlający właściwości obiektu, własne emocje z nim związane oraz uruchamiane wobec niego programy działań (Wojciszke, 1988). Niewątpliwie żaden akt regulacyjny nie może dojść do skutku, jeżeli nie opiera się równocześnie na rozpoznaniu tego, co aktualnie się dzieje oraz na wartościowaniu danego zdarzenia. Łączny wynik obu procesów doprowadza do ukształtowania lub wyboru odpowiedniej formy zachowania (Reykowski, 1988).

Funkcjonowanie człowieka w trudnej sytuacji zależy w dużej mierze od dokonania przez niego oceny położenia, w jakim się znalazł. Ocena poznawcza sytuacji jest procesem kategoryzacji zdarzeń z punktu widzenia ich znaczenia dla dobrostanu jednostki (Włodarczyk, 1999). Szczególna rola oceny poznawczej zaznacza się podczas trudnych sytuacji, które zakłócają dotychczasowy tok czynności, zagrażają człowiekowi, utrudniają bądź uniemożliwiają mu realizację potrzeb. Zdarzenie stresowe może zostać ocenione jako krzywda/strata (dotyczy poniesionych szkód i strat związanych z ważnymi obiektami i przedmiotami), zagrożenie (odnosi się do podobnych szkód, które jeszcze nie wystąpiły i są antycypowane) i wyzwanie (wskazuje na możliwość opanowania sytuacji trudnej i zyskania czegoś) (Włodarczyk, Wrześniewski, 2005). Indywidualna ocena danej sytuacji trudnej wpływa na decyzje jednostki dotyczące możliwości podjęcia działania usuwającego przyczyny sytuacji trudnej lub przynajmniej łagodzącej jej skutki, określanego jako strategia zaradcza (Heszen-Niejodek, 2002). Wiele badań wskazuje, że istotnym czynnikiem determinującym wybór postępowania w konflikcie jest sposób jego spostrzegania. Wyniki badań, na które powołują się Mario Mikulincer i Victor Florian (1995), Mark H. Anshel i Bruce Wells (2000), 
Kent Kowalski, Peter Crocker i Sharleen Hoar (2005) oraz Dorota Domińska-Werbel (2014) wykazały, że ocena sytuacji w kategoriach zagrożenia lub krzyw$\mathrm{dy} /$ straty skłania jednostkę do stosowania strategii destruktywnych, nastawionych na obniżenie przykrego napięcia i łagodzenie negatywnych stanów emocjonalnych wynikających z trudnej sytuacji, natomiast ocena sytuacji w kategoriach wyzwania wiąże się z podejmowaniem strategii konstruktywnych zorientowanych na poradzenie sobie z trudnościami. Na podstawie uzyskanych wyników Dean Pruitt, Jeffrey Rubin i Sung Hee Kim (1994), Daniel Bar-Tal (1993) oraz Janusz Reykowski (2002) ustalili, że konflikt interesów może być interpretowany zarówno w kategoriach zagrożenia i wykluczenia, które zakładają konieczność walki i rywalizacji, jak i wspólnego dążenia do rozwiązania problemu, które generuje możliwość reinterpretacji sprzecznych celów i rozwiązania rozbieżności. Dążenie do konfrontacji i eskalacja wrogości mają miejsce, gdy konflikt interesów jest postrzegany jako sytuacja, w której realizacja celów jest możliwa tylko przez całkowite zwycięstwo własne i całkowitą porażkę drugiej strony. Strona przeciwna przestaje być partnerem, staje się wrogiem. Odbierana jest jako zagrożenie dla realizacji własnych celów i wartości. Zasadniczo osoby oceniające sytuację jako krzywda/strata lub zagrożenie w przypadku wystąpienia konfliktu są agresywne i atakujące. Do kooperacji, wspólnego rozwiązania problemu i wzajemnego ustępstwa dochodzi wtedy, gdy konflikt postrzegany jest jako sytuacja złożona, w której dążenie obu stron zasługuje na realizację. Z kolei w badaniach Geneviève Bouchard (2003), w których sprawdzana była zależność między oceną poznawczą sytuacji a radzeniem sobie w konflikcie małżeńskim, wykazano, że pary małżeńskie oceniające konflikt jako zagrożenie z większym prawdopodobieństwem wybierają strategie unikowe/dystansujące.

Generalnie należy uznać, że od wyniku oceny poznawczej w kategoriach zagrożenie, krzywda/strata czy wyzwanie zależy, w jaki sposób adolescent poradzi sobie w sytuacji konfliktu społecznego, której doświadcza w środowisku szkolnym, grupie rówieśniczej oraz domu rodzinnym.

Człowiek na sytuacje zagrażające reaguje emocjonalnie. Reakcje emocjonalne w sytuacji zagrażającej są związane z cechami osobowości człowieka, a także ze sposobem spostrzegania przez niego sytuacji (Łosiak, 1995). Sytuacja konfliktowa, która stanowi immanentny element interakcji społecznych, wywołuje silne napięcie emocjonalne o negatywnym zabarwieniu. Człowiek w wyniku oddziaływania czynników prowokujących (jak np. konflikt) może doświadczać uczuć gniewu i złości (Deffenbacher, 1992; Łosiak, 2009). Gniew czy złość to jedyne z możliwych reakcji emocjonalnych o znaku ujemnym, które pojawiają się podczas doświadczania sytuacji stresowej postrzeganej jako zagrożenie lub strata/ krzywda (Wrześniewski, 1991; Lazarus, 2000; Balawajder, 2010). Utrzymujące się pobudzenie emocjonalne o dużym nasileniu i zabarwieniu negatywnym stanowi podstawę do zachowań agresywnych, irytacji, wybuchów wściekłości i innych 
z pozoru nieuzasadnionych reakcji emocjonalnych, które można zaobserwować w różnego typu zachowaniach o charakterze destrukcyjnym (Terelak, 2001). Analiza materiału badawczego (Różańska-Kowal, 2004; Łosiak, 2009; Domińska-Werbel, 2014) wykazała, że skłonność młodego człowieka do reagowania gniewem i złością jest powiązana z podejmowaniem walki, niepoddawaniem się w sytuacjach trudnych.

Inną z możliwych reakcji emocjonalnych o znaku ujemnym, wywołanych przez sytuacje zagrożenia obiektywnego lub subiektywnego, zewnętrznego lub wewnętrznego, działającego aktualnie lub w przyszłości, jest lęk (Doliński, 2000). Jest to na ogół stan przykry dla człowieka, dlatego dąży on do uwolnienia się od tej emocji. Wyniki badań (Nitendel-Bujakowa, 2001; Borecka-Biernat, 2006; Łosiak, 2009; Domińska-Werbel, 2014; Sikorski, 2015) wykazały, że emocje w sekwencji niepokój - lęk - strach na ogół prowadzą do ucieczki i oddalenia się od obiektu wyzwalającego daną emocję czy podporządkowania się inicjatywie innych i ustępliwości.

Powszechnie znane jest stwierdzenie, że lęk, pomimo swojej charakterystyki polegającej na oddalaniu się od potencjalnego zagrożenia, leży u podłoża zachowania agresywnego (Kępiński, 1992; Ranschburg, 1993). Możliwość współwystępowania lęku i agresji znajduje poparcie w wynikach badań Wiesława Sikorskiego (2015). Okazało się, że uczniowie w obliczu konfliktu z rówieśnikami „atakują problem”, nie dążą do jego rozwiązania czy złagodzenia, używają siły fizycznej przeciw osobom czy przedmiotom i/lub manifestują swoje nieprzychylne nastawienie wobec innych w postaci wypowiedzi poniżających, krzywdzących i oskarżających.

Niewątpliwie wpływ lęku na zachowanie zależy od jego nasilenia. Badania Marka Leary'ego i Robina Kowalskiego (2001) oraz Lee Clarka i David Watsona (2002) wykazały, że niskie nasilenie lęku działa mobilizująco na zachowanie jednostki, natomiast duże nasilenie je dezorganizuje, ponieważ sprzyja postrzeganiu wielu sytuacji jako zagrażających, nawet jeśli obiektywnie takimi nie są.

Istnieje jednak część badań, w których autorzy wyrażają pogląd, że trudne sytuacje spostrzegane jako wyzwanie mogą spowodować u człowieka wystąpienie pozytywnych reakcji emocjonalnych i zadowolenie z możliwości przezwyciężenia trudności (Lazarus, 1991; Spielberger, Starr, 1994). Jak się okazuje, ciekawość jest emocją pozytywną towarzyszącą zdarzeniom niespodziewanym. Motywuje ona do poszukiwania nowych informacji oraz zachęca do poszerzania doświadczeń. Odzwierciedla też pragnienie odkrywania, poznawania i rozumienia nowych, niejednoznacznych cech środowiska (Voss, Keller, 1983; Doliński, 2000; Spielberger, Reheiser, 2009). Większa ciekawość sprzyja silniejszemu przekonaniu o umiejętności znajdowania dróg do osiągnięcia celu i mobilizowania się do wysiłku, a co za tym idzie przekonaniu o możliwości poradzenia sobie z trudnościami (Łaguna, Bąk, 2007). Stymuluje ona zatem zachowania poszukiwawcze 
i eksploracyjne, które przyczyniają się do rozwiązania problemów (Fredickson, 2001; Spielberger, Reheiser, 2003).

Podsumowując, można stwierdzić, że sytuacje trudne generują emocje pozytywne, w szczególności ciekawość, która wyzwala strategie aktywnego zmagania się z trudnościami, a także emocje negatywne (gniew, lęk), przy czym te ostatnie są na ogół stanem przykrym dla młodego człowieka, dlatego dąży on do uwolnienia się od nich. Broniąc się przed nimi, stosuje agresję, która zakłada konieczność zbliżenia się do przedmiotu zagrożenia, aby go zniszczyć lub uszkodzić, co umożliwia zredukowanie napięcia emocjonalnego, lub wycofuje się czy ulega sytuacji, w której musiałoby dojść do konfrontacji jego napięcia emocjonalnego z realnym lub przewidywanym zagrożeniem (Watson, Clark, 1999; Lemerise, Dodge, 2005).

\section{PYTANIE I HIPOTEZA BADAWCZA}

Badania empiryczne skupiono wokół problemu osobowościowych uwarunkowań destruktywnej (agresji, uniku, uległości) i konstruktywnej (zadaniowej) strategii radzenia sobie młodzieży w sytuacji konfliktu społecznego, ze szczególnym zwróceniem uwagi na rolę rodzaju oceny poznawczej sytuacji konfliktu społecznego oraz poziomu i treści emocji. W ramach tego problemu sformułowano podstawowe pytanie badawcze: Jaki zespół zmiennych osobowościowych jest podstawą występowania destruktywnej i konstruktywnej strategii radzenia sobie dziewcząt i chłopców w sytuacji konfliktu społecznego?

Tak sformułowane pytanie badawcze pozwala na postawienie następującej hipotezy, której weryfikacji posłuży analiza wyników przeprowadzonych badań empirycznych: Dziewczęta i chłopcy oceniający sytuacje konfliktu jako zagrożenie lub strata/krzywda i o wysokim poziomie emocji negatywnych (gniew, lęk) częściej podejmują destruktywną strategię radzenia sobie w sytuacji konfliktu społecznego, a dziewczęta i chłopcy oceniający sytuacje konfliktu jako wyzwanie i o wysokim poziomie emocji pozytywnych (ciekawość) częściej aktywizują konstruktywną strategię radzenia sobie w sytuacji konfliktu społecznego.

\section{METODY BADAŃ WŁASNYCH}

W badaniach zastosowano następujące metody. Kwestionariusz Oceny Stresu (KOS) autorstwa Doroty Włodarczyk i Kazimierza Wrześniewskiego (2010) zawierający 35 (w tym 23 diagnostycznych) przymiotnikowych określeń oceniających sytuacje stresowe. Składa się z dwóch wersji, które obejmują te same zestawy przymiotnikowych określeń, a różnią się instrukcją podawaną osobom badanym. W wersji A (pomiar sytuacyjnej oceny stresu) osoby badane proszone są o wskazanie konkretnej sytuacji trudnej, która miała miejsce w ciągu ostatniego tygodnia (w opisywanym badaniu była to sytuacja konfliktu społecznego). 
Wersja B (pomiar dyspozycyjnej oceny stresu) zawiera instrukcję, w której osoby badane proszone są o zaznaczenie, $\mathrm{w}$ jakim stopniu podane przymiotniki są zgodne z tym, czego najczęściej doświadczają w sytuacjach trudnych (w opisywanym badaniu były to sytuacje konfliktu społecznego). KOS składa się z sześciu podskal, będących wskaźnikami poszczególnych rodzajów oceny stresu. Są to: zagrożenie-stan, zagrożenie-cecha, krzywda/strata-stan, krzywda/strata-cecha, wyzwanie-stan i wyzwanie-cecha. Podskale „zagrożenia” zawierają 10 pozycji, podskale „wyzwanie” - 6 pozycji, a „krzywda/strata” - 4 pozycje. Kwestionariusz charakteryzuje się zadowalającą rzetelnością (współczynnik zgodności wewnętrznej $\alpha$ Cronbacha dla wersji A wynosi $0,76-0,90$, a dla wersji B - 0,79-0,90) oraz trafnością czynnikową i trafnością kryterialną.

Trójczynnikowy Inwentarz Stanów i Cech Osobowości (TISCO) jest polską adaptacją amerykańskiego testu State-Trait Personality Inventory (STPI) opracowanego przez zespół Charlesa D. Spielbergera (Wrześniewski, 1991). TISCO składa się z dwóch niezależnych części. Część pierwsza (SPI) jest przeznaczona do pomiaru lęku, gniewu i ciekawości, traktowanych jako stan (state) emocjonalny, odczuwany w danym momencie. Część druga (TPI) używana jest do badania tych samych emocji, traktowanych jako cecha (trait) osobowości. Test zawiera 6 podskal: lęk jako stan i lęk jako cecha, gniew jako stan i gniew jako cecha oraz ciekawość jako stan i ciekawość jako cecha. Każda z podskal składa się z 10 krótkich, prostych stwierdzeń odnoszących się do subiektywnych odczuć jednostki. Rzetelność polskiej wersji Inwentarza TISCO jest zbliżona do oryginalnej wersji STPI. Współczynniki zgodności wewnętrznej $\alpha$ Cronbacha wynoszą 0,82-0,92 dla części pierwszej (SPI), dla części drugiej zaś (TPI) $0,68-0,88$ w zależności od próby. Trafność TISCO sprawdzono w dwóch zakresach: trafności teoretycznej i trafności diagnostycznej. Wyniki dotyczące trafności TISCO są zadowalające i zbliżone do oryginalnej wersji STPI.

Kwestionariusz KSMK opracowany przez Danutę Borecką-Biernat (2012) przeznaczony jest do badania strategii radzenia sobie w sytuacji konfliktu społecznego podejmowanej przez młodzież w wieku dorastania. Składa się z opisu 33 sytuacji konfliktu społecznego. Do każdej podano 4 zachowania wyrażające radzenie sobie z sytuacją konfliktu społecznego - pierwsze odnosi się do agresywnego radzenia (,A”), drugie do unikowego radzenia („U”), trzecie do uległego radzenia („Ul”), a czwarte do zadaniowego (konstruktywnego) radzenia sobie w sytuacji konfliktu społecznego (,Z”). Wyniki uzyskuje się dla każdej skali oddzielnie poprzez sumowanie zaznaczonych zachowań w 33 sytuacjach należących do danej skali. Kwestionariusz charakteryzuje się dobrą rzetelnością (współczynnik zgodności wewnętrznej $\alpha$ Cronbacha wynosi około bądź powyżej 0,70 ) i trafnością diagnostyczną. 


\section{OSOBY BADANE}

Badania empiryczne przeprowadzono w szkołach gimnazjalnych we Wrocławiu i w okolicznych miejscowościach. Przebadano grupę 468 (52,4\%) dziewczynek i $425(47,6 \%)$ chłopców w wieku 13-15 lat. Ogółem w przeprowadzonych badaniach wzięły udział 893 osoby. Badani byli uczniami pierwszych, drugich i trzecich klas gimnazjalnych w podobnych proporcjach: 39\%, 32\% i 29\%. Zastosowano wybór losowy szkół, jednak nie wszystkie wylosowane szkoły zgodziły się na przeprowadzenie $\mathrm{w}$ nich badań, dlatego w kilku przypadkach zwrócono się do szkół niewylosowanych, z którymi tego rodzaju współpraca była możliwa. Wszystkim badanym uczniom zapewniono dobrowolność udziału w badaniach i anonimowość, a badania zostały przeprowadzone zgodnie z zasadami psychologicznych badań naukowych.

Podstawowym kryterium doboru badanych uczniów był wiek. Wpływ wieku na dobór strategii radzenia sobie w sytuacji konfliktu społecznego analizowano w grupie wiekowej 13-15 lat (podokres wczesnej adolescencji). Wiek dorastania jest ważnym etapem w życiu każdego człowieka, ponieważ jest uważany za moment przejściowy między dzieciństwem a dorosłością. Określany jest też jako okres buntu i naporu. Dokonuje się wówczas wiele zmian biologicznych, psychicznych, mentalnych, motywacyjnych i w postawach społecznych, które sprawiają, że młodzież ma niejednokrotnie wiele problemów z dostosowaniem swojego postępowania do nowych sytuacji, zadań i ról społecznych (Czerwińska-Jasiewicz, 2003). Ze względu na rozwój krytycznej oceny otaczającej rzeczywistości i wzmożone kształtowanie się obrazu własnej osoby, supremację sfery uczuciowej nad innymi dziedzinami życia psychicznego oraz nowe formy kontaktów społecznych i bezpośredniość w zachowaniu młodzież w wieku 13-15 lat wydaje się dobrym podmiotem badań do poznania strategii destruktywnego (agresja, unik, uległość) i konstruktywnego (zadanie) radzenia sobie w sytuacji silnego napięcia emocjonalnego, jaką jest konflikt społeczny.

\section{ANALIZA WYNIKÓW BADAŃ}

W celu ustalenia, jaki zespół zmiennych osobowościowych przewiduje poziom strategii radzenia sobie w sytuacji konfliktu społecznego u młodzieży, zdecydowano się na zastosowanie regresji w wariancie hierarchicznym z wykorzystaniem metody eliminacji wstecznej (kryterium: prawdopodobieństwo F-usunięcia $\geq 0,100$ ). Metoda polega na wprowadzeniu do modelu wszystkich potencjalnych predyktorów, a następnie sukcesywnym usuwaniu nieistotnych zmiennych, po których następuje ponowne przeliczanie modelu aż do uzyskania ostatecznej postaci (Bedyńska, Książek, 2012). Za zmienną zależną przyjęto wyniki w czterech skalach kwestionariusza KSMK: agresywne radzenie 
sobie w sytuacji konfliktu społecznego („A”), unikowe radzenie sobie w sytuacji konfliktu społecznego („U”), uległe radzenie sobie w sytuacji konfliktu społecznego („Ul”) i zadaniowe radzenie sobie w sytuacji konfliktu społecznego (,Z”). Jako zbiór zmiennych niezależnych potraktowano wyniki w sześciu skalach (Zagrożenie-stan i Zagrożenie-cecha, Krzywda/Strata-stan i Krzywda/ Strata-cecha, Wyzwanie-stan i Wyzwanie-cecha) kwestionariusza KOS i w sześciu skalach (Gniew-stan i Gniew-cecha, Lęk-stan i Lęk-cecha, Ciekawość-stan i Ciekawość-cecha) Trójczynnikowego Inwentarza Stanów i Cech Osobowości TISCO. Wyniki przedstawiono w tabelach 1-4.

Tabela 1. Krokowa regresja wielokrotna dla wyniku skali Agresja („A”) KSMK względem skal kwestionariuszy KOS i TISCO - wyniki dla całej grupy $(\mathrm{N}=893)$ oraz dla dziewcząt $(\mathrm{N}=468)$ i chłopców $(\mathrm{N}=425)$

\begin{tabular}{|c|c|c|c|c|c|c|}
\hline Osoby badane & Zmienna & Beta & B & Błąd std. B & $\mathrm{t}$ & Poziom $\mathrm{p}<$ \\
\hline \multirow{7}{*}{ Ogółem } & Zagrożenie-stan & 0,08 & 0,06 & 0,02 & 2,58 & 0,01 \\
\hline & Gniew-stan & 0,19 & 0,13 & 0,03 & 4,44 & 0,00001 \\
\hline & Lęk-stan & $-0,08$ & $-0,12$ & 0,06 & $-2,08$ & 0,04 \\
\hline & Gniew-cecha & 0,31 & 0,23 & 0,03 & 7,34 & 0,0000001 \\
\hline & Lęk-cecha & $-0,09$ & $-0,08$ & 0,04 & $-2,29$ & 0,02 \\
\hline & Ciekawość-cecha & $-0,09$ & $-0,09$ & 0,043 & $-2,74$ & 0,006 \\
\hline & W. wolny & - & 3,64 & 1,39 & 2,63 & 0,009 \\
\hline \multicolumn{7}{|c|}{$\begin{array}{c}\text { Współczynnik korelacji wielokrotnej: } \mathrm{R}=0,38 \\
\text { Współczynnik wielokrotnej determinacji: } \mathrm{R}^{2}=0,14 \\
\text { Istotność równania: } \mathrm{F}(6,886)=24,59 ; \mathrm{p}<0,00001 \\
\text { Błąd std. estymacji: } 4,32\end{array}$} \\
\hline \multirow{7}{*}{ Dziewczęta } & Zagrożenie-stan & 0,12 & 0,08 & 0,03 & 2,60 & 0,01 \\
\hline & Gniew-stan & 0,23 & 0,17 & 0,04 & 4,01 & 0,00007 \\
\hline & Lęk-stan & $-0,17$ & $-0,24$ & 0,07 & $-3,21$ & 0,001 \\
\hline & Gniew-cecha & 0,34 & 0,25 & 0,04 & 5,72 & 0,0000001 \\
\hline & Lęk-cecha & $-0,14$ & $-0,13$ & 0,05 & $-2,49$ & 0,01 \\
\hline & Ciekawość-cecha & $-0,10$ & $-0,09$ & 0,04 & $-2,09$ & 0,04 \\
\hline & W. wolny & - & 5,75 & 1,84 & 3,12 & 0,002 \\
\hline \multicolumn{7}{|c|}{$\begin{array}{c}\text { Współczynnik korelacji wielokrotnej: } \mathrm{R}=0,40 \\
\text { Współczynnik wielokrotnej determinacji: } \mathrm{R}^{2}=0,16 \\
\text { Istotność równania: } \mathrm{F}(6,461)=14,78 ; \mathrm{p}<0,000001 \\
\text { Błąd std. estymacji: } 4,28\end{array}$} \\
\hline \multirow{4}{*}{ Chłopcy } & Gniew-stan & 0,15 & 0,11 & 0,04 & 2,91 & 0,004 \\
\hline & Ciekawość-stan & $-0,11$ & $-0,11$ & 0,05 & $-2,39$ & 0,02 \\
\hline & Gniew-cecha & 0,26 & 0,20 & 0,04 & 5,05 & 0,000001 \\
\hline & W. wolny & - & 2,20 & 1,46 & 1,51 & 0,13 \\
\hline \multicolumn{7}{|c|}{$\begin{array}{c}\text { Współczynnik korelacji wielokrotnej: } \mathrm{R}=0,37 \\
\text { Współczynnik wielokrotnej determinacji: } \mathrm{R}^{2}=0,14 \\
\text { Istotność równania: } \mathrm{F}(3,421)=22,44 ; \mathrm{p}<0,000001 \\
\text { Błąd std. estymacji: } 4,31\end{array}$} \\
\hline
\end{tabular}

Źródło: opracowanie własne. 
Pierwszą analizę przeprowadzono na wynikach całej grupy badanej młodzieży, bez względu na płeć. Jak widać w tabeli 1, sześć zmiennych miało istotny wpływ na strategię agresywnego radzenia sobie młodzieży w sytuacji konfliktu społecznego: sytuacyjna ocena konfliktu jako zagrożenie, gniew ujmowany jako stan emocjonalny i gniew ujmowany jako cecha osobowości, lęk ujmowany jako stan emocjonalny i lęk ujmowany jako cecha osobowości oraz ciekawość ujmowana jako cecha osobowości. Współczynnik korelacji wielokrotnej wynosi $\mathrm{R}=0,38 \mathrm{i}$ wskazuje, że związek liniowy między strategią agresywnego radzenia sobie młodzieży w sytuacji konfliktu społecznego a łącznym wpływem wymienionych zmiennych jest niski. Zmienne te wyjaśniają $14 \%$ wariancji zmiennej zależnej $\left(\mathrm{R}^{2}=0,14 ; \mathrm{F}(6,886)=24,59 ; \mathrm{p}<0,00001\right)$. Pozostałe zmienne uwzględnione w badaniu okazały się nieistotnymi wyznacznikami strategii agresji w grupie młodzieży. Wartości Beta wskazują, że im wyższy poziom sytuacyjnej oceny konfliktu jako zagrożenie, wyższy poziom gniewu rozumiany jako chwilowy stan emocjonalny przeżywany w związku z sytuacją konfliktu i wyższy poziom wyuczonej dyspozycji behawioralnej do reagowania gniewem, niższy poziom lęku rozumianego jako chwilowy stan emocjonalny przeżywany w związku z sytuacją konfliktu i niższy poziom wyuczonej dyspozycji behawioralnej do reagowania lękiem oraz niższy poziom wyuczonej dyspozycji behawioralnej do reagowania ciekawością, tym wyższy poziom strategii agresywnego radzenia sobie osób dorastających w sytuacji konfliktu społecznego.

Przeprowadzono odrębne analizy dla grup wydzielonych ze względu na płeć (tabela 1). Krokowa analiza regresji wykazała, że spośród dwunastu zmiennych niezależnych wprowadzonych do modelu regresji sześć miało istotne znaczenie w wyjaśnianiu strategii agresywnego radzenia sobie stosowanej przez dziewczęta w sytuacji konfliktu społecznego. Pozostałe zmienne uwzględnione w badaniu okazały się nieistotnymi wyznacznikami strategii agresji u dziewcząt. Z obliczeń wynika, że ważną rolę determinującą dla strategii agresywnego radzenia sobie przez dziewczęta odgrywają: sytuacyjna ocena konfliktu jako zagrożenie, gniew ujmowany jako stan emocjonalny i gniew ujmowany jako cecha osobowości, lęk ujmowany jako stan emocjonalny i lęk ujmowany jako cecha osobowości oraz ciekawość ujmowana jako cecha osobowości. Współczynnik korelacji wielokrotnej wynosi $\mathrm{R}=0,40 \mathrm{i}$ wskazuje, że związek liniowy między strategią agresywnego radzenia sobie dziewcząt w sytuacji konfliktu społecznego a łącznym wpływem wymienionych zmiennych jest umiarkowany. Te zmienne niezależne wyjaśniają $16 \%$ wariancji zmiennej zależnej $\left(\mathrm{R}^{2}=0,16, \mathrm{~F}(6,461)=14,78 ; \mathrm{p}<0,000001\right)$. Parametry równania regresyjnego, w tym jego istotność, świadczą o tym, że im wyższy poziom sytuacyjnej oceny konfliktu jako zagrożenie, wyższy poziom gniewu rozumiany jako chwilowy stan emocjonalny odczuwany w związku z sytuacją konfliktu społecznego i wyższy poziom wyuczonej dyspozycji behawioralnej do reagowania gniewem, niższy poziom lęku rozumianego jako chwilowy stan emo- 
cjonalny przeżywany w związku z sytuacją konfliktu i niższy poziom wyuczonej dyspozycji behawioralnej do reagowania lękiem oraz niższy poziom wyuczonej dyspozycji behawioralnej do reagowania ciekawością, tym wyższy poziom strategii agresywnego radzenia sobie dziewcząt w sytuacji konfliktu społecznego.

Ponadto sprawdzono, jaki zespół zmiennych osobowościowych warunkuje w sytuacji konfliktu społecznego strategię agresywnego radzenia sobie chłopców. Trzy zmienne niezależne okazały się istotne w równaniu regresyjnym. Są to: gniew ujmowany jako stan emocjonalny, gniew ujmowany jako cecha osobowości oraz ciekawość ujmowana jako stan emocjonalny. Współczynnik korelacji wielokrotnej wynosi $\mathrm{R}=0,37$ i wskazuje, że związek liniowy między strategią agresywnego radzenia sobie chłopców w sytuacji konfliktu społecznego a łącznym wpływem wymienionych zmiennych jest niski. Współczynnik wielokrotnej determinacji $\left(\mathrm{R}^{2}=0,14(\mathrm{~F}(3,421)=22,44 ; \mathrm{p}<0,000001)\right.$ wskazuje, że $14 \%$ zmienności w zakresie strategii agresywnego radzenia sobie chłopców w sytuacji konfliktu społecznego daje się wyjaśnić oddziaływaniem przyjętego zespołu zmiennych niezależnych. Pozostałe zmienne uwzględnione w badaniu okazały się nieistotnymi wyznacznikami strategii agresji w grupie chłopców. Wartości Beta świadczą o tym, że im wyższy poziom gniewu rozumianego jako chwilowy stan emocjonalny odczuwany w związku z sytuacją konfliktu społecznego i wyższy poziom wyuczonej dyspozycji behawioralnej do reagowania gniewem oraz niższy poziom ciekawości rozumianej jako chwilowy stan emocjonalny, tym wyższy poziom strategii agresywnego radzenia sobie chłopców w sytuacji konfliktu społecznego.

Przeprowadzona dotychczas analiza materiału empirycznego była ześrodkowana na strategii agresywnego radzenia sobie młodzieży w sytuacji konfliktu społecznego. Nasuwa się pytanie, jaki zespół zmiennych osobowościowych okaże się istotny dla całej grupy badanej młodzieży i dla obu grup wyodrębnionych ze względu na płeć stosujących w działaniu formę radzenia sobie o charakterze unikającym. Na to pytanie odpowiadają wyniki kolejnej analizy regresji, co przedstawia tabela 2.

Spośród dwunastu zmiennych osobowościowych w równaniu regresyjnym istotny wpływ na strategie unikowego radzenia sobie młodzieży w sytuacji konfliktu społecznego mają: sytuacyjna ocena konfliktu jako krzywda/strata, gniew ujmowany jako stan emocjonalny, gniew ujmowany jako cecha osobowości oraz ciekawość ujmowana jako cecha osobowości. Współczynnik korelacji wielokrotnej wynosi $\mathrm{R}=0,29$ i wskazuje, że związek liniowy między strategią unikowego radzenia sobie młodzieży w sytuacji konfliktu społecznego a łącznym wpływem wymienionych zmiennych jest niski. Współczynnik determinacji wielokrotnej jest równy $8 \%$ i wskazuje, że uwzględniony zespół zmiennych niezależnych wyjaśnia tylko część tej zmiennej zależnej $\left(\mathrm{R}^{2}=0,08 ; \mathrm{F}(4,888)=19,75 ; \mathrm{p}<0,000001\right)$. Wartości Beta świadczą o tym, że im wyższy poziom dyspozycyjnej oceny kon- 
Tabela 2. Krokowa regresja wielokrotna dla wyniku skali Unik („U”) KSMK względem skal kwestionariuszy KOS i TISCO: wyniki dla całej grupy $(\mathrm{N}=893)$ oraz dla dziewcząt $(\mathrm{N}=468)$ i chłopców $(\mathrm{N}=425)$

\begin{tabular}{|c|c|c|c|c|c|c|}
\hline $\begin{array}{l}\text { Osoby } \\
\text { badane }\end{array}$ & Zmienna & Beta & B & Błąd std. B & $\mathrm{t}$ & Poziom $\mathrm{p}<$ \\
\hline Ogółem & $\begin{array}{c}\text { Krzywda/ } \\
\text { Strata-cecha } \\
\text { Gniew-stan } \\
\text { Gniew-cecha } \\
\text { Ciekawość-cecha } \\
\text { W. wolny }\end{array}$ & $\begin{array}{r}0,11 \\
0,12 \\
0,14 \\
-0,16 \\
-\end{array}$ & $\begin{array}{r}0,12 \\
0,06 \\
0,08 \\
-0,11 \\
3,53\end{array}$ & $\begin{array}{l}0,04 \\
0,02 \\
0,02 \\
0,02 \\
0,77\end{array}$ & $\begin{array}{r}3,27 \\
3,25 \\
3,81 \\
-4,72 \\
4,60\end{array}$ & $\begin{array}{l}0,001 \\
0,001 \\
0,0002 \\
0,000003 \\
0,0000005\end{array}$ \\
\hline \multicolumn{7}{|c|}{$\begin{array}{c}\text { Współczynnik korelacji wielokrotnej: } \mathrm{R}=0,29 \\
\text { Współczynnik wielokrotnej determinacji: } \mathrm{R}^{2}=0,08 \\
\text { Istotność równania: } \mathrm{F}(4,888)=19,75 ; \mathrm{p}<0,000001 \\
\text { Błąd std. estymacji: } 3,33\end{array}$} \\
\hline Dziewczęta & $\begin{array}{c}\text { Krzywda/ } \\
\text { Strata-cecha } \\
\text { Gniew-stan } \\
\text { Gniew-cecha } \\
\text { Ciekawość-cecha } \\
\text { W. wolny }\end{array}$ & $\begin{array}{r}0,14 \\
0,12 \\
0,11 \\
-0,14 \\
-\end{array}$ & $\begin{array}{r}0,17 \\
0,06 \\
0,07 \\
-0,09 \\
3,24\end{array}$ & $\begin{array}{l}0,06 \\
0,03 \\
0,03 \\
0,03 \\
1,01\end{array}$ & $\begin{array}{r}2,99 \\
2,30 \\
2,01 \\
-2,85 \\
3,20\end{array}$ & $\begin{array}{l}0,003 \\
0,02 \\
0,05 \\
0,005 \\
0,002\end{array}$ \\
\hline \multicolumn{7}{|c|}{$\begin{array}{c}\text { Współczynnik korelacji wielokrotnej: } \mathrm{R}=0,27 \\
\text { Współczynnik wielokrotnej determinacji: } \mathrm{R}^{2}=0,07 \\
\text { Istotność równania: } \mathrm{F}(4,463)=8,80 ; \mathrm{p}<0,000001 \\
\text { Błąd std. estymacji: } 3,30\end{array}$} \\
\hline Chłopcy & \begin{tabular}{|c|} 
Krzywda/ \\
Strata-cecha \\
Lęk-stan \\
Gniew-cecha \\
Ciekawość-cecha \\
W. wolny
\end{tabular} & $\begin{array}{r}0,11 \\
0,14 \\
0,21 \\
-0,20 \\
-\end{array}$ & $\begin{array}{r}0,13 \\
0,16 \\
0,12 \\
-0,15 \\
1,34\end{array}$ & $\begin{array}{l}0,05 \\
0,06 \\
0,03 \\
0,04 \\
1,57\end{array}$ & $\begin{array}{r}2,39 \\
2,91 \\
4,28 \\
-4,20 \\
0,85\end{array}$ & $\begin{array}{l}0,02 \\
0,004 \\
0,00002 \\
0,00003 \\
0,40\end{array}$ \\
\hline \multicolumn{7}{|c|}{$\begin{array}{c}\text { Współczynnik korelacji wielokrotnej: } \mathrm{R}=0,34 \\
\text { Współczynnik wielokrotnej determinacji: } \mathrm{R}^{2}=0,12 \\
\text { Istotność równania: } \mathrm{F}(4,420)=13,72 ; \mathrm{p}<0,000001 \\
\text { Błąd std. estymacji: } 3,33\end{array}$} \\
\hline
\end{tabular}

Źródło: opracowanie własne.

fliktu jako krzywda/strata, wyższy poziom gniewu rozumiany jako chwilowy stan emocjonalny przeżywany w związku z sytuacją konfliktu i wyższy poziom wyuczonej dyspozycji behawioralnej do reagowania gniewem oraz niższy poziom wyuczonej dyspozycji behawioralnej do reagowania ciekawością, tym wyższy poziom strategii unikowego radzenia sobie osób dorastających w sytuacji konfliktu społecznego.

Czy te same zmienne osobowości okażą się istotne dla dziewcząt? W tym celu przeprowadzono odrębne analizy dla grup wydzielonych ze względu na płeć 
(tabela 2). Tylko cztery zmienne osobowościowe okazały się istotne w równaniu regresyjnym. Na poziom strategii unikowego radzenia sobie u dziewcząt mają wpływ: dyspozycyjna ocena konfliktu jako krzywda/strata, gniew ujmowany jako stan emocjonalny, gniew ujmowany jako cecha osobowości oraz ciekawość ujmowana jako cecha osobowości. Współczynnik korelacji wielokrotnej wynosi $\mathrm{R}=0,27$ i wskazuje, że związek liniowy między strategią unikowego radzenia sobie dziewcząt w sytuacji konfliktu społecznego a łącznym wpływem wymienionych zmiennych jest niski. Współczynnik determinacji jest niewysoki $\left(\mathrm{R}^{2}=0,07\right)$, co oznacza, że jedynie 7\% zmienności unikowego sposobu radzenia sobie dziewcząt w sytuacji konfliktu społecznego zostało wyjaśnione oddziaływaniem przyjętego zespołu zmiennych niezależnych $(\mathrm{F}(4,463)=8,80 ; \mathrm{p}<0,000001)$. Pozostałe zmienne niezależne uwzględnione $\mathrm{w}$ badaniu okazały się nieistotnymi wyznacznikami strategii uniku w grupie dziewcząt. Wartości Beta wskazują, że im wyższa dyspozycyjna ocena konfliktu jako krzywda/strata, wyższy poziom gniewu rozumiany jako chwilowy stan emocjonalny przeżywany w związku z sytuacją konfliktu i wyższy poziom wyuczonej dyspozycji behawioralnej do reagowania gniewem oraz niższy poziom wyuczonej dyspozycji behawioralnej do reagowania ciekawością, tym wyższy poziom strategii unikowego radzenia sobie dziewcząt w sytuacji konfliktu społecznego.

Jaki zespół zmiennych osobowościowych okaże się istotny dla chłopców? $\mathrm{Na}$ to pytanie odpowiadają wyniki kolejnej analizy regresji przedstawione w tabeli 2 . Spośród dwunastu zmiennych tylko cztery okazały się istotne w równaniu regresyjnym. Są to: sytuacyjna ocena konfliktu jako krzywda/strata, lęk ujmowany jako stan emocjonalny, gniew ujmowany jako cecha osobowości oraz ciekawość ujmowana jako cecha osobowości. Współczynnik korelacji wielokrotnej wynosi $\mathrm{R}=0,34$ i wskazuje, że związek liniowy między strategią unikowego radzenia sobie chłopców w sytuacji konfliktu społecznego a łącznym wpływem wymienionych zmiennych jest niski. Współczynnik determinacji jest równy $\mathrm{R}^{2}=0,12$ i wskazuje, że $12 \%$ zmiennej zależnej, jaką jest strategia unikowego radzenia sobie u chłopców, jest wyjaśnione przez te zmienne $(F(4,420)=13,72$; $\mathrm{p}<0,000001)$. Wartości Beta świadczą o tym, że im wyższy poziom sytuacyjnej oceny konfliktu jako krzywda/strata, wyższy poziom lęku rozumiany jako chwilowy stan emocjonalny odczuwany w związku z sytuacją konfliktu społecznego i wyższy poziom wyuczonej dyspozycji behawioralnej do reagowania gniewem oraz niższy poziom wyuczonej dyspozycji behawioralnej do reagowania ciekawością, tym wyższy poziom strategii unikowego radzenia sobie chłopców w sytuacji konfliktu społecznego.

Model regresji wielokrotnej dla strategii uległego radzenia sobie w sytuacji konfliktu społecznego jako zmiennej wyjaśnianej przedstawia tabela 3. 
Tabela 3. Krokowa regresja wielokrotna dla wyniku skali Uległość („Ul”) KSMK względem skal kwestionariuszy KOS i TISCO: wyniki dla całej grupy $(\mathrm{N}=893)$ oraz dla dziewcząt $(\mathrm{N}=468)$ i chłopców $(\mathrm{N}=425)$

\begin{tabular}{|c|c|c|c|c|c|c|}
\hline $\begin{array}{l}\text { Osoby } \\
\text { badane }\end{array}$ & Zmienna & Beta & $\mathrm{B}$ & Błąd std. B & $\mathrm{t}$ & Poziom $\mathrm{p}<$ \\
\hline Ogółem & $\begin{array}{l}\text { Gniew-stan } \\
\text { Lęk-stan } \\
\text { Gniew-cecha } \\
\text { W. wolny }\end{array}$ & $\begin{array}{r}-0,09 \\
0,13 \\
-0,23 \\
-\end{array}$ & $\begin{array}{r}-0,06 \\
0,18 \\
-0,17 \\
7,88\end{array}$ & $\begin{array}{l}0,03 \\
0,05 \\
0,03 \\
1,08\end{array}$ & $\begin{array}{r}-2,15 \\
3,26 \\
-6,49 \\
7,28\end{array}$ & $\begin{array}{l}0,03 \\
0,001 \\
0,0000001 \\
0,0000001\end{array}$ \\
\hline \multicolumn{7}{|c|}{$\begin{array}{c}\text { Współczynnik korelacji wielokrotnej: } \mathrm{R}=0,27 \\
\text { Współczynnik wielokrotnej determinacji: } \mathrm{R}^{2}=0,07 \\
\text { Istotność równania: } \mathrm{F}(3,889)=23,23 ; \mathrm{p}<0,000001 \\
\text { Błąd std. estymacji: } 4,31\end{array}$} \\
\hline Dziewczęta & $\begin{array}{l}\text { Gniew-stan } \\
\text { Lęk-stan } \\
\text { Gniew-cecha } \\
\text { W. wolny }\end{array}$ & $\begin{array}{r}-0,16 \\
0,16 \\
-0,23 \\
-\end{array}$ & $\begin{array}{r}-0,12 \\
0,21 \\
-0,16 \\
7,49\end{array}$ & $\begin{array}{l}0,04 \\
0,07 \\
0,03 \\
1,41\end{array}$ & $\begin{array}{r}-2,81 \\
2,91 \\
-4,68 \\
5,30\end{array}$ & $\begin{array}{l}0,005 \\
0,004 \\
0,000004 \\
0,0000001\end{array}$ \\
\hline \multicolumn{7}{|c|}{$\begin{array}{c}\text { Współczynnik korelacji wielokrotnej: } \mathrm{R}=0,30 \\
\text { Współczynnik wielokrotnej determinacji: } \mathrm{R}^{2}=0,10 \\
\text { Istotność równania: } \mathrm{F}(3,464)=15,20 ; \mathrm{p}<0,000001 \\
\text { Błąd std. estymacji: } 4,24\end{array}$} \\
\hline Chłopcy & $\begin{array}{l}\text { Wyzwanie-cecha } \\
\text { Gniew-cecha } \\
\text { W. wolny }\end{array}$ & $\begin{array}{r}-0,11 \\
-0,23 \\
-\end{array}$ & $\begin{array}{r}-0,13 \\
-0,17 \\
11,98\end{array}$ & $\begin{array}{l}0,05 \\
0,03 \\
0,84\end{array}$ & $\begin{array}{l}-2,31 \\
-4,80 \\
14,19\end{array}$ & $\begin{array}{l}0,002 \\
0,000002 \\
0,0000001\end{array}$ \\
\hline \multicolumn{7}{|c|}{$\begin{array}{c}\text { Współczynnik korelacji wielokrotnej: } \mathrm{R}=0,26 \\
\text { Współczynnik wielokrotnej determinacji: } \mathrm{R}^{2}=0,07 \\
\text { Istotność równania: } \mathrm{F}(2,422)=15,37 ; \mathrm{p}<0,000001 \\
\text { Błąd std. estymacji: } 4,34\end{array}$} \\
\hline
\end{tabular}

Źródło: opracowanie własne.

Wyniki wskazują, że istotny wpływ na strategię uległości młodzieży (badani ogółem) w sytuacji konfliktu społecznego mają: gniew ujmowany jako stan emocjonalny, gniew ujmowany jako cecha osobowości i lęk ujmowany jako stan emocjonalny. Współczynnik korelacji wielokrotnej wynosi $\mathrm{R}=0,27$ i wskazuje, że związek liniowy między strategią uległego radzenia sobie młodzieży w sytuacji konfliktu społecznego a łącznym wpływem wymienionych zmiennych jest niski. Wyjaśniona wariancja dla strategii uległości młodzieży wynosi $7 \%\left(\mathrm{R}^{2}=0,07 ; \mathrm{F}(3,889)=23,23 ; \mathrm{p}<0,00001\right)$. Pozostałe zmienne niezależne uwzględnione $\mathrm{w}$ badaniu okazały się nieistotnymi wyznacznikami strategii uległości w grupie młodzieży. Wartości Beta wskazują, że im niższy poziom gniewu rozumiany jako chwilowy stan emocjonalny przeżywany w związku z sytuacją konfliktu i niższy poziom wyuczonej dyspozycji behawioralnej do reagowania gniewem oraz wyższy poziom lęku rozumiany jako chwilowy stan emocjonalny odczuwany w związku z sytuacją konfliktu społecznego, tym wyż- 
szy poziom strategii uległego radzenia sobie młodzieży w sytuacji konfliktu społecznego.

Czy taki sam zespół zmiennych osobowości okaże się istotny dla dziewcząt i chłopców, którzy w radzeniu sobie w sytuacji konfliktu społecznego częściej stosują strategie uległości? Na to pytanie odpowiadają wyniki kolejnej analizy regresji, co przedstawia tabela 3 .

Krokowa analiza regresji wykazała, że spośród wprowadzonych do modelu regresji zmiennych trzy miały istotne znaczenie w wyjaśnianiu strategii uległego radzenia sobie stosowanej przez dziewczęta w sytuacji konfliktu społecznego. Są to: gniew ujmowany jako stan emocjonalny, gniew ujmowany jako cecha osobowości i lęk ujmowany jako stan emocjonalny. Współczynnik korelacji wielokrotnej wynosi $\mathrm{R}=0,30$ i wskazuje, że związek liniowy między strategią uległego radzenia sobie dziewcząt w sytuacji konfliktu społecznego a łącznym wpływem wymienionych zmiennych jest niski. Łącznie te zmienne wyjaśniają $10 \%$ zmienności wyników dziewcząt w skali „Ul” kwestionariusza KSMK $\left(\mathrm{R}^{2}=0,10\right.$; $\mathrm{F}(3,464)=15,20 ; \mathrm{p}<0,000001)$. Pozostałe zmienne niezależne $\mathrm{w}$ badaniu okazały się nieistotnymi wyznacznikami strategii uległości u dziewcząt. Wartości Beta wskazują, że im niższy poziom gniewu rozumiany jako chwilowy stan emocjonalny przeżywany w związku z sytuacją konfliktu i niższy poziom wyuczonej dyspozycji behawioralnej do reagowania gniewem oraz wyższy poziom lęku rozumiany jako chwilowy stan emocjonalny odczuwany w związku z sytuacją konfliktu społecznego, tym częściej dziewczęta w radzeniu sobie w sytuacji konfliktu społecznego wykorzystują strategie uległości.

Z kolei parametry równania regresyjnego, w tym jego istotność, świadczą o tym, że dyspozycyjna ocena poznawcza konfliktu jako wyzwanie i gniew ujmowany jako cecha osobowości ma istotny wpływ na poziom strategii uległego radzenia sobie w sytuacji konfliktu społecznego, stosowanej w grupie chłopców (tabela 3). Współczynnik korelacji wielokrotnej wynosi $\mathrm{R}=0,26$ i wskazuje, że związek liniowy między strategią uległego radzenia sobie chłopców w sytuacji konfliktu społecznego a łącznym wpływem wymienionych zmiennych jest niski. Współczynnik determinacji $\left(\mathrm{R}^{2}=0,07\right)$ wskazuje, że 7\% zmiennej zależnej, jaką jest strategia uległego radzenia sobie u chłopców, jest wyjaśnione przez te zmienne $(\mathrm{F}(2,422)=15,37 ; \mathrm{p}<0,000001)$. Parametry równania regresyjnego, $\mathrm{w}$ tym jego istotność, świadczą o tym, że im niższy poziom dyspozycyjnej oceny konfliktu w kategorii wyzwania i niższy poziom wyuczonej dyspozycji behawioralnej do reagowania gniewem, tym wyższy poziom strategii uległego radzenia sobie chłopców w sytuacji konfliktu społecznego.

W dalszych analizach zmienną zależną była strategia zadaniowego radzenia sobie młodzieży w sytuacji konfliktu społecznego. Wyniki analizy regresji wielokrotnej dla całej badanej grupy oraz dla grup wydzielonych ze względu na płeć przedstawia tabela 4. 
Tabela 4. Krokowa regresja wielokrotna dla wyniku skali Zadanie („Z”) KSMK względem skal kwestionariuszy KOS i TISCO: wyniki dla całej grupy $(\mathrm{N}=893)$ oraz dla dziewcząt $(\mathrm{N}=468)$ i chłopców $(\mathrm{N}=425)$

\begin{tabular}{|c|c|c|c|c|c|c|}
\hline $\begin{array}{l}\text { Osoby } \\
\text { badane }\end{array}$ & Zmienna & Beta & B & Błąd std. B & $\mathrm{t}$ & Poziom $\mathrm{p}<$ \\
\hline Ogółem & $\begin{array}{c}\text { Krzywda/Strata-cecha } \\
\text { Gniew-stan } \\
\text { Gniew-cecha } \\
\text { Ciekawość-cecha } \\
\text { W. wolny }\end{array}$ & $\begin{array}{r}-0,07 \\
-0,15 \\
-0,12 \\
0,18 \\
-\end{array}$ & $\begin{array}{r}-0,16 \\
-0,15 \\
-0,12 \\
0,23 \\
16,76\end{array}$ & $\begin{array}{l}0,08 \\
0,04 \\
0,04 \\
0,05 \\
1,42\end{array}$ & $\begin{array}{r}-2,15 \\
-4,03 \\
-3,10 \\
5,12 \\
11,78\end{array}$ & $\begin{array}{l}0,03 \\
0,00006 \\
0,002 \\
0,0000001 \\
0,0000001\end{array}$ \\
\hline \multicolumn{7}{|c|}{$\begin{array}{c}\text { Współczynnik korelacji wielokrotnej: } \mathrm{R}=0,29 \\
\text { Współczynnik wielokrotnej determinacji: } \mathrm{R}^{2}=0,09 \\
\text { Istotność równania: } \mathrm{F}(4,888)=20,83 ; \mathrm{p}<0,000001 \\
\text { Błąd std. estymacji: } 6,20\end{array}$} \\
\hline Dziewczęta & $\begin{array}{c}\text { Gniew-stan } \\
\text { Gniew-cecha } \\
\text { Ciekawość-cecha } \\
\text { W. wolny }\end{array}$ & $\begin{array}{r}-0,10 \\
-0,11 \\
0,16 \\
-\end{array}$ & $\begin{array}{r}-0,10 \\
-0,11 \\
0,20 \\
16,53\end{array}$ & $\begin{array}{l}0,05 \\
0,05 \\
0,06 \\
1,84\end{array}$ & $\begin{array}{r}-2,01 \\
-2,11 \\
3,29 \\
9,00\end{array}$ & $\begin{array}{l}0,00007 \\
0,05 \\
0,04 \\
0,0000001\end{array}$ \\
\hline \multicolumn{7}{|c|}{$\begin{array}{c}\text { Współczynnik korelacji wielokrotnej: } \mathrm{R}=0,23 \\
\text { Współczynnik wielokrotnej determinacji: } \mathrm{R}^{2}=0,05 \\
\text { Istotność równania: } \mathrm{F}(3,464)=8,48 ; \mathrm{p}<0,00002 \\
\text { Błąd std. estymacji: } 6,18\end{array}$} \\
\hline Chłopcy & $\begin{array}{l}\text { Lęk-stan } \\
\text { Gniew-cecha } \\
\text { Ciekawość-cecha } \\
\text { W. wolny }\end{array}$ & $\begin{array}{r}-0,18 \\
-0,19 \\
0,22 \\
-\end{array}$ & $\begin{array}{r}-0,37 \\
-0,20 \\
0,31 \\
20,08\end{array}$ & $\begin{array}{l}0,10 \\
0,05 \\
0,06 \\
2,85\end{array}$ & $\begin{array}{r}-3,73 \\
-3,95 \\
4,80 \\
7,05\end{array}$ & $\begin{array}{l}0,0002 \\
0,00009 \\
0,000002 \\
0,0000001\end{array}$ \\
\hline \multicolumn{7}{|c|}{$\begin{array}{c}\text { Współczynnik korelacji wielokrotnej: } \mathrm{R}=0,35 \\
\text { Współczynnik wielokrotnej determinacji: } \mathrm{R}^{2}=0,12 \\
\text { Istotność równania: } \mathrm{F}(3,421)=19,85 ; \mathrm{p}<0,000001 \\
\text { Błąd std. estymacji: } 6,11\end{array}$} \\
\hline
\end{tabular}

Źródło: opracowanie własne.

Wyznacznikami strategii zadaniowej jako sposobu radzenia sobie w sytuacji konfliktu społecznego młodzieży (badani ogółem) są: dyspozycyjna ocena konfliktu jako krzywda/strata, gniew ujmowany jako stan emocjonalny, gniew ujmowany jako cecha osobowości oraz ciekawość ujmowana jako cecha osobowości. Pozostałe zmienne niezależne uwzględnione w badaniu okazały się nieistotnymi wyznacznikami strategii zadaniowej stosowanej przez młodzież w sytuacji konfliktu społecznego. Współczynnik korelacji wielokrotnej wynosi $\mathrm{R}=0,29$ i wskazuje, że związek liniowy między strategią zadaniowego radzenia sobie młodzieży w sytuacji konfliktu społecznego a łącznym wpływem wymienionych zmiennych jest niski. Współczynnik wielokrotnej determinacji $\left(\mathrm{R}^{2}=0,09\right)$ wskazuje, że 9\% wariancji zmiennej zależnej „strategia zadaniowa” w grupie młodzieży zostało wyjaśnione oddziaływaniem przyjętego zespołu zmiennych niezależnych 
$(\mathrm{F}(4,488)=20,83 ; \mathrm{p}<0,000001)$. Wartości Beta świadczą o tym, że im niższy poziom dyspozycyjnej oceny konfliktu w kategorii krzywda/strata, niższy poziom gniewu rozumiany jako chwilowy stan emocjonalny przeżywany w związku z sytuacją konfliktu społecznego i niższy poziom wyuczonej dyspozycji behawioralnej do reagowania gniewem oraz wyższy poziom wyuczonej dyspozycji behawioralnej do reagowania ciekawością, tym wyższy poziom strategii zadaniowego radzenia sobie osób dorastających w sytuacji konfliktu społecznego.

Czy ten sam zespół zmiennych osobowości okaże się istotny dla dziewcząt i chłopców, którzy w radzeniu sobie w sytuacji konfliktu społecznego częściej stosują strategię zadaniową? Na to pytanie odpowiadają wyniki kolejnej analizy regresji, co przedstawia tabela 4 .

Krokowa analiza regresji wykazała, że spośród wprowadzonych do modelu regresji zmiennych trzy miały istotne znaczenie w wyjaśnianiu strategii zadaniowego radzenia sobie stosowanej przez dziewczęta w sytuacji konfliktu społecznego. Są to: gniew ujmowany jako stan emocjonalny, gniew ujmowany jako cecha osobowości oraz ciekawość ujmowana jako cecha osobowości. Współczynnik korelacji wielokrotnej wynosi $\mathrm{R}=0,23$ i wskazuje, że związek liniowy między strategią zadaniowego radzenia sobie dziewcząt w sytuacji konfliktu społecznego a łącznym wpływem wymienionych zmiennych jest niski. Łącznie te zmienne niezależne wyjaśniają 5\% zmienności wyników dziewcząt w skali „Z” kwestionariusza KSMK $(\mathrm{F}(3,464)=8,48 ; \mathrm{p}<0,00002)$. Pozostałe zmienne niezależne w badaniu okazały się nieistotnymi wyznacznikami strategii zadaniowej u dziewcząt. Wartości Beta świadczą o tym, że im niższy poziom gniewu rozumiany jako chwilowy stan emocjonalny przeżywany w związku z sytuacją konfliktu społecznego i niższy poziom wyuczonej dyspozycji behawioralnej do reagowania gniewem oraz wyższy poziom wyuczonej dyspozycji do reagowania ciekawością, tym częściej dziewczęta w radzeniu sobie w sytuacji konfliktu społecznego wykorzystują strategię zadaniową.

Dużą rolę w warunkowaniu strategii zadaniowej stosowanej przez chłopców w sytuacji konfliktu społecznego odgrywają: lęk ujmowany jako stan emocjonalny, gniew ujmowany jako cecha osobowości oraz ciekawość ujmowana jako cecha osobowości. Wartości Beta wskazują, że im niższy poziom lęku rozumiany jako chwilowy stan emocjonalny odczuwany w związku z sytuacją konfliktu społecznego, niższy poziom wyuczonej dyspozycji behawioralnej do reagowania gniewem i wyższy poziom wyuczonej dyspozycji do reagowania ciekawością, tym częściej chłopcy w radzeniu sobie w sytuacji konfliktu społecznego stosują strategię zadaniową. Współczynnik korelacji wielokrotnej wynosi $\mathrm{R}=0,35$ i wskazuje, że związek liniowy między strategią zadaniowego radzenia sobie chłopców w sytuacji konfliktu społecznego a łącznym wpływem wymienionych zmiennych jest niski. Współczynnik determinacji wielokrotnej dla strategii zadaniowej wykorzystywanej w sytuacji konfliktu przez chłopców wynosi $12 \%$ 
i świadczy o tym, że ten zespół zmiennych wyjaśnia część wariancji zmiennej zależnej $(\mathrm{F}(3,421)=19,85 ; \mathrm{p}<0,000001)$.

W świetle przeprowadzonej weryfikacji statystycznej można stwierdzić, że uzyskane wyniki pozwoliły częściowo zweryfikować słuszność przedstawionej w części metodologicznej hipotezy badawczej. Warto zaznaczyć, że wyodrębnione zmienne osobowościowe nie są silnymi predyktorami destruktywnej (agresji, uniku, uległości) i konstruktywnej (zadaniowej) strategii radzenia sobie młodzieży w sytuacji konfliktu społecznego, o czym świadczy wynik $\mathrm{R}^{2}=0,05-0,16$. Biorąc pod uwagę stosunkowo niski współczynnik wielokrotnej determinacji, nasuwa się wniosek, że może istnieć wiele innych zmiennych współdeterminujących poziom destruktywnej i konstruktywnej strategii radzenia sobie młodzieży w sytuacji konfliktu społecznego, które nie zostały uwzględnione w tym badaniu.

\section{DYSKUSJA WYNIKÓW}

Poznawcze ustosunkowanie młodego człowieka do sytuacji konfliktu społecznego może mieć wpływ na wybór strategii zaradczej. Analiza wyników badań ujawniła, że sytuacyjna ocena określająca konflikt jako zagrożenie wiąże się ze strategią agresywnego radzenia sobie młodzieży w sytuacji konfliktu społecznego. Należy sądzić, że odczuwanie zagrożenia sprzyja generowaniu niechęci i postawom agresywnym wobec innych. Tendencja ta wydaje się zgodna z twierdzeniem Leonarda Berkowitza (1992), że agresja powstaje w człowieku w rezultacie postrzeganego zagrożenia czy na skutek przekonania, że jest się obiektem intencjonalnego, niewłaściwego traktowania i naruszenia własnej wartości. Zbliżone wyniki uzyskali Deborah J. Terry (1994), K. Kowalski i współpracownicy (2005) oraz D. Włodarczyk i K. Wrześniewski (2010), którzy ujawnili, że osoba oceniająca sytuację trudną w kategoriach zagrożenia korzysta z takich środków zaradczych, które uwolnią ją (choć na krótki czas) od poczucia zagrożenia, tego przykrego stanu. W swoim repertuarze strategii posiada ona takie, które są skoncentrowane na redukcji przykrych emocji, a nie na rozwiązaniu problemu. W ramach strategii zorientowanej emocjonalnie jednostka aktywnie zwalcza sytuację trudną w celu jej pokonania. Agresja jako strategia jest formą nieracjonalnego (emocjonalnego) zachowania i braku umiejętności radzenia sobie z sytuacjami trudnymi, które napotyka często młody człowiek (Kossewska, 2008). Młodzież reprezentująca wyższe nasilenie oceny konfliktu w środowisku szkolnym i pozaszkolnym w kategorii zagrożenia w swoim zachowaniu ujawnia więc agresję przyjmującą formę ataku fizycznego i/lub werbalnego skierowanego wobec osób.

Nie można zapominać, że jednostka na sytuację zagrożenia reaguje emocjonalnie. Odczuwanie emocji negatywnych prowadzi do działań skierowanych na usunięcie zagrożenia oraz przywrócenie utraconych obiektów i celów działania (Doliński, 2000). Konflikty interpersonalne są przez młodzież uważane za stan 
zagrożenia, deklarują oni wysoki poziom stresu w związku z nimi (Guszkowska $i$ in., 2001). Należy więc przypuszczać, że kiedy sytuacja konfliktu zostaje oceniona jako zagrożenie, to wyzwala w jednostce emocje negatywne, co w konsekwencji wywołuje strategie agresji (Berkowitz, 1989; Kubacka-Jasiecka, 2006; Fung, Gerstein, Chan, Engebretson, 2015; Sikorski, 2015). W efekcie w obliczu konfliktu jednostka ,atakuje problem”, nie dąży do jego rozwiązania czy złagodzenia, używa siły fizycznej przeciw osobom czy przedmiotom i/lub manifestuje swoje nieprzychylne nastawienie wobec innych w postaci wypowiedzi oskarżających, krzywdzących i poniżających. Agresywny wzór zachowania pomaga rozładować u dorastającej młodzieży emocje negatywne, pojawiające się w sytuacji stwarzającej zagrożenie dla realizacji jej własnych dążeń. Na podstawie analizy zebranego materiału badawczego należy stwierdzić, że wpływ na strategie agresywnego radzenia sobie w sytuacji konfliktu społecznego ma gniew jako stan emocjonalny odczuwany w związku z konfliktem i wyuczona dyspozycja behawioralna do reagowania gniewem. Można przypuszczać, że wraz ze wzrostem poziomu gniewu o zróżnicowanej genezie (stan, cecha) zwiększa się nasilenie strategii agresywnego radzenia sobie młodzieży w sytuacji konfliktu społecznego (Deffenbacher, 1992; Łosiak, 2009; Domińska-Werbel, 2014). Rezultat taki wydaje się odpowiadać konkluzji, którą sformułował Siergiej Rubinsztejn (1964, s. 612), według którego „w związku z powstawaniem społecznych sprzeczności jako realnych faktów emocjonalnych, rodzi się ludzkie oburzenie, zgorszenie, wrogość, nienawiść".

Istotnym czynnikiem determinującym wybór postępowania w konflikcie jest sposób jego postrzegania (Reykowski, 2002). W badaniach stwierdzono, że młodzież wykorzystująca strategie uniku w sytuacji konfliktu społecznego charakteryzuje się wyższą sytuacyjną i dyspozycyjną oceną konfliktu w kategorii krzywda/strata. Pozwala to przypuszczać, że strategia ta jest właściwie decyzją, czy warto angażować się w konflikt czy nie, podczas podejmowania której poddawane są ocenie możliwe zyski i straty (Antonini, 1998). Jest ona preferowana w sytuacji, gdy koszty bądź ryzyko angażowania się w konflikt są duże, a możliwe zyski są niewystarczające. W momencie gdy młody człowiek spostrzega, że działanie partnera doprowadziło już do pewnych szkód, związanych np. z poczuciem własnej wartości, jest on skłonny wycofać się z sytuacji konfliktu. Tłumaczy to niejako uzyskane związki tej strategii z oceną konfliktu jako krzywda/strata, gdy jednostka nie ma już nic do zdobycia i jest przekonana o nieodwracalności tej sytuacji. Ucieczka z sytuacji konfliktu prowadzi do zaniechania celów działań pod wpływem trudności. Unikanie konfrontacji z konfliktem, polegające zarówno na podjęciu przez jednostkę dodatkowych czynności angażujących uwagę (np. oglądanie telewizji, objadanie się, spanie), odwracających ją od sytuacji konfliktu, jak i na poszukiwaniu kontaktu z innymi ludźmi jest wyrazem obrony siebie przed zaistniałą szkodą w postaci utraty wartości materialnych lub osobistych, takich jak zdrowie, prestiż społeczny, 
bliska osoba czy rodzina (Heszen-Niejodek, 2002). Zarysowująca się tendencja wydaje się zgodna z wynikami uzyskanymi przez M. Mikulincera i V. Floriana (1995), M. Anshela i B. Wellsa (2000), G. Bouchard (2003), D. Włodarczyk i K. Wrześniewskiego (2010) oraz D. Domińską-Werbel (2014).

Przeprowadzone badania wykazały, że doświadczana przez dorastających sytuacja konfliktu społecznego może przyczynić się do przeżywania emocji negatywnych (lęk, gniew) oraz dyskomfortu spowodowanego trudnościami w rozwiązywaniu problemu. Stwierdzono, że młodzież podejmująca strategie uniku w sytuacji konfliktu społecznego przejawia istotnie wyższy poziom chwilowego stanu emocji negatywnych, wyższy poziom wyuczonej dyspozycji do reagowania emocjami negatywnymi oraz niższy poziom wyuczonej dyspozycji do reakcji ciekawości. Można przypuszczać, że osiągając znaczny poziom intensywności, emocje negatywne obniżają ciekawość poznawczą, hamują spontaniczną aktywność, zmniejszają motywację do podejmowania transgresyjnych czynów, uruchamiają zachowania typu ,ucieczka” (wycofanie, unikanie) z sytuacji zagrożenia czy sytuacji szkód i strat, te zaś służą obniżeniu negatywnego pobudzenia emocjonalnego, przynajmniej na pewien czas (Leary, Kowalski, 2001).

Analiza przedstawionych wyników badań wykazała, że niższa dyspozycyjna ocena konfliktu w kategorii wyzwania sprzyja nasileniu strategii uległego radzenia sobie w sytuacji konfliktu społecznego. $Z$ tego, co wiemy, wynika, że postrzeganie danej sytuacji jako wyzwania wiąże się z koncentracją na potencjalnym zysku i mobilizacją, a co za tym idzie z nastawieniem na walkę i osiąganie celów, co jest sprzeczne z uleganiem (Bjorck, Cuthberston, Thurman, Yung, 2001; Włodarczyk, Wrześniewski, 2010). Adolescent oceniający konflikt jako wyzwanie nie będzie zatem ustępować w sporach, nie będzie ulegać i odwrotnie. Stwierdzony związek wskazuje, że im bardziej nastolatek skłonny jest do uległego radzenia sobie, tym mniej skłonny jest oceniać sytuacje konfliktu w kategoriach antycypowanych korzyści, a mniejsza tendencja do uległego radzenia sobie wiąże się z większą skłonnością do postrzegania konfliktu jako wyzwanie. Przypuszczalnie adolescent, który zauważa, że nie istnieje szansa na osiągnięcie korzyści, może dojść do wniosku, że być może lepszą strategią radzenia sobie będzie uległość względem partnera konfliktu niż angażowanie się w działanie skierowane przeciwko partnerowi i podejmowanie walki oraz narażanie się na większe szkody, zwłaszcza gdy uzna, że cel, do którego dąży, nie jest tak istotny (Balawajder, 2010).

Konflikt społeczny jest zjawiskiem nierozerwalnie związanym z emocjami. Przedstawione rezultaty badań wskazują, że podwyższony poziom lęku u młodzieży dorastającej sprzyja pojawieniu się uległych form zachowania, podporządkowaniu się inicjatywie innych oraz ustępliwości w sytuacji konfliktu. Wynik ten nie jest sprzeczny z doniesieniami innych badań, które wskazują, że strategię uległości opisuje podwyższony poziom lęku, który powoduje chęć pójścia na całko- 
wite ustępstwa wobec partnera sporu (Trower, Gilbert, 1989; Oleś, 1998; Drabek, Merecz, Mościcka, 2005; Weeks, Rodebaugh, Heimberg, Norton, Jakatdar, 2009; Balawajder, 2010; Wright, London, Waechter, 2010; Zimmerman, Morrison, Heimberg, 2015). Oznacza to, że obawa przed odrzuceniem i potrzeba pozostania w dobrych relacjach za cenę rezygnacji z własnych interesów w sporze prowadzi do nadmiernego podporządkowania się inicjatywie innych. Rezygnacja jednostki z realizacji własnych celów na rzecz podporządkowania się celom partnera interakcji daje jej pewną rękojmię zwiększenia poczucia bezpieczeństwa (Hass, Mann, 1976). Ponadto badania ewolucyjne donoszą, że jest to strategia charakterystyczna także dla zwierząt, które stosują uległość w celu redukcji lęku przed silniejszym osobnikiem (Gilbert, 2001).

W świetle dokonanej weryfikacji statystycznej można zauważyć, że niższa tendencja do dyspozycyjnej oceny konfliktu w kategorii krzywda/strata sprzyja nasileniu strategii zadaniowej radzenia sobie młodzieży w sytuacji konfliktu społecznego. Wydaje się, że młodzież radząca sobie w sposób zadaniowy nie postrzega jej jako utraty wartości osobistych, pozycji społecznej czy bliskiej osoby. Różni autorzy (Lazarus, Folkman, 1984; Mikulincer, Florian, 1995; Bjorck i in., 2001; Domińska-Werbel, 2014) wielokrotnie wskazywali, że postrzeganie określonej sytuacji w kategoriach krzywdy/straty skłania jednostkę do podejmowania zachowań umożliwiających zredukowanie negatywnych emocji, a nie na rozwiązanie problemu. W momencie gdy człowiek stwierdza, że ma możliwość wywierania wpływu na przebieg zdarzenia stresowego, częściej wybiera strategię zadaniową, zorientowaną na problem. Pomimo przesłanek teoretycznych i empirycznych nie potwierdziły się związki między sytuacyjną i dyspozycyjną oceną poznawczą konfliktu jako wyzwania ze strategią zadaniową. Być może brak oczekiwanych związków wynika z faktu, że jest to strategia trudna do osiągnięcia oraz rzadko spotykana (Wojciszke, 2011). To, że dana osoba uzyskiwała wysoki wynik w skali „Z” w kwestionariuszu KSMK, może wynikać z faktu, iż jest to narzędzie wymuszonego wyboru, gdzie z czterech opcji trzeba wybrać tę bardziej preferowaną, w związku z tym jednostka z małą tendencją do pewnych strategii wybiera strategię zadaniową, mimo że nie stosuje jej w codziennym życiu. Jest to pewna wada narzędzi tego typu.

Młodzież wykorzystująca w sytuacji konfliktu społecznego strategię zadaniową przejawia wyższy poziom emocji ciekawości o zróżnicowanej genezie (stan, cecha). Ciekawość jako pozytywna emocja pełni u niej funkcję czynnika motywującego do podjęcia działań ukierunkowanych na poradzenie sobie ze zdarzeniami, które je wywołały (Frijda, 2002). Sprzyja ona myśleniu i twórczości oraz zwiększa elastyczność reakcji, co wzmacnia eksperymentowanie, odkrywanie nowych zjawisk i szukanie nowych rozwiązań (Fredrickson, 2001). Rezultat taki wydaje się odpowiadać konkluzji, którą sformułował Dariusz Doliński (2000, s. 446): „(...) ciekawość z perspektywy sytuacyjnej jawi się jako reakcja 
na zmianę (nowość), a dyspozycyjnie jako pewną gotowość (niski próg) reagowania na wszelkie zmiany i innowacje, wspólną miarą zaś ciekawości dyspozycyjnej i sytuacyjnej jest preferencja nowości, a zatem szukanie rozwiązań w sytuacjach trudnych i nowych". Jak się okazuje, ciekawość prowadzi do przekonania o zdolności znajdowania drogi do celu, mobilizuje jednostkę do podejmowania wysiłku i sprzyja przekonaniu o zdolności pokonania trudności (Łaguna, Bąk, 2007). Warto zaznaczyć, że w ujęciu ewolucyjnym otwartość na zbieranie informacji (ciekawość) oznacza przygotowanie do lepszego i zadaniowego radzenia sobie w sytuacjach trudnych, również w przyszłości (DeCatanzaro, 2003). Analiza wyników potwierdziła, że im wyższy poziom ciekawości jako stanu emocjonalnego, odczuwany w związku z konfliktem, oraz wyższy poziom ciekawości jako dyspozycji do reagowania na wszelkie zmiany i innowacje, tym silniejsze u młodzieży dążenie do porozumienia się z partnerem w celu znalezienia obopólnie korzystnego rozwiązania problemu, który ujawnił się w postaci konfliktu. W literaturze znajdują się opisy badań, które potwierdzają zaobserwowaną zależność, chociażby takich autorów, jak: D. Doliński (2000), Barbara L. Fredrickson (2001), Denys A. DeCatanzaro (2003), Irena Jelonkiewicz, Katarzyna Kosińska-Dec (2008) i D. Domińska-Werbel (2014).

Reasumując, wydaje się, że ocena sytuacji konfliktu w kategorii zagrożenia lub krzywdy/straty oraz reagowanie na nią gniewem lub lękiem generalnie współwystępuje $\mathrm{z}$ tendencją do destruktywnego reagowania na konflikt, natomiast niespostrzeganie konfliktu jako krzywdy/straty oraz reagowanie na nią ciekawością stwarza większe możliwości konstruktywnego zmagania się z sytuacją konfliktu społecznego.

\section{BIBLIOGRAFIA}

Anshel, M.H., Wells, B. (2000). Personal and Situational Variables that Describe Coping with Acute Stress in Competitive Sport. Journal of Social Psychology, 140(4), 434-450.

DOI: https://doi.org/10.1080/00224540009600483

Antonini, D. (1998). Relationship between the Big Five Personality Factors and Conflict Management Styles. International Journal of Conflict Management, 9(4), 336-355.

DOI: https://doi.org/10.1108/eb022814

Balawajder, K. (2010). Zachowania uczestników konfliktu interpersonalnego. W: D. Borecka-Biernat (red.), Sytuacje konfliktu w środowisku rodzinnym, szkolnym i rówieśniczym. Jak sobie radza z nimi dzieci i młodzież? (s. 137-179). Warszawa: Difin.

Bar-Tal, D. (1993). Przekonania społeczne w czasie nierozwiązywalnych konfliktów. Studia Psychologiczne, (2), 175-198.

Bedyńska, S., Książek, M. (2012). Praktyczny przewodnik wykorzystania modeli regresji oraz równań strukturalnych. Warszawa: Akademickie Sedno.

Berkowitz, L. (1989). Frustration-aggression hypothesis: Examination and reformulation. Psychological Bulletin, 106(1), 59-73. DOI: https://doi.org/10.1037/0033-2909.106.1.59

Berkowitz, L. (1992). O powstawaniu i regulowaniu gniewu i agresji. Nowiny Psychologiczne, (1-2), $87-105$. 
Bjorck, J., Cuthberston, W., Thurman, J., Yung, S. (2001). Ethnicity, Coping and Distress among Korean American, Filipino American and Caucasian Americans. Journal of Social Psychology, 141(4), 421-443. DOI: https://doi.org/10.1080/00224540109600563

Borecka-Biernat, D. (2006). Strategie radzenia sobie młodzieży w trudnych sytuacjach społecznych. Psychospołeczne uwarunkowania. Wrocław: Wydawnictwo Uniwersytetu Wrocławskiego.

Borecka-Biernat, D. (2012). Kwestionariusz strategii radzenia sobie młodzieży w sytuacji konfliktu społecznego. Psychologia Wychowawcza, 44(1-2), 86-118.

DOI: https://doi.org/10.5604/00332860.1094162

Bouchard, G. (2003). Cognitive Appraisals, Neuroticism, and Openness as Correlates of Coping Strategies: An Integrative Model of Adaptation to Marital Difficulties. Canadian Journal of Behavioural Science, 35(1), 1-12. DOI: https://doi.org/10.1037/h0087181

Clark, L., Watson, D. (2002). Funkcjonalne i dysfunkcjonalne reakcje uczuciowe. W: P. Ekman, R. Dawidson (red.), Natura emocji. Podstawowe zagadnienia (s. 119-125). Gdańsk: GWP.

Czerwińska-Jasiewicz, M. (2003). Społeczno-kulturowe podejście do dorastania. W: A. Jurkowski (red.), Zzagadnień wspótczesnej psychologii wychowawczej (s. 208-226). Warszawa: Wydawnictwo Instytutu Psychologii PAN.

DeCatanzaro, D.A. (2003). Motywacje i emocje w ujęciu ewolucyjnym, fizjologicznym, rozwojowym i społecznym. Poznań: Zysk i S-ka.

Deffenbacher, J. (1992). Trait anger: Theory, findings and implications. W: C. Spielberger, J. Butcher (eds.), Advances in Personality Assessment (s. 177-201). Hillsdale: Lawrence Erlbaum Associates.

Doliński, D. (2000). Emocje, poznanie i zachowanie. W: J. Strelau (red.), Psychologia. Podręcznik akademicki (T. 2; s. 369-394). Gdańsk: GWP.

Domińska-Werbel, D. (2014). Psychologiczne uwarunkowania strategii radzenia sobie młodzieży gimnazjalnej $w$ trudnych sytuacjach spolecznych. Legnica: WPWSZ.

Donaldson, D., Prinstein, M., Danovsky, M., Spirito, A. (2000). Patterns of children's coping with life stress: Implications with clinicians. American Journal of Orthopsychiatry, 70(3), 351-359. DOI: https://doi.org/10.1037/h0087689

Drabek, M., Merecz, D., Moscicka, A. (2005). Cecha lęku i wzór zachowania (typu a i b) jako modyfikatory bezpośrednich reakcji na przemoc. Medycyna Pracy, 56(3), 223-234.

Eschenbeck, H., Kohlmann, C., Lohaus, A. (2007). Gender differences in doping strategies in children and adolescents. Journal of Individual Differences, 28, 18-26.

DOI: https://doi.org/10.1027/1614-0001.28.1.18

Frączek, A. (2003). Wszystko o twojej agresji. Charaktery, (7), 28-30.

Fredrickson, B.L. (2001). The role of positive emotions in positive psychology. American Psychologist, 56(3), 218-226. DOI: https://doi.org/10.1037/0003-066X.56.3.218

Frijda, N. (2002). Emocje są funkcjonalne na ogół. W: P. Ekman, R. Davidson (red.), Natura emocji. Podstawowe zagadnienia (s. 20-24). Gdańsk: GWP.

Fung, A., Gerstein, L., Chan, Y., Engebretson, J. (2015). Relationship of Aggression to Anxiety, Depression, Anger and Empathy in Hong Kong. Journal of Child \& Family Studies, 24(3), 821-831. DOI: https://doi.org/10.1007/s10826-013-9892-1

Gawryś, M. (2002). Rozwiązywanie konfliktów w klasie. Edukacja i Dialog, (8), 35-39.

Gilbert, P. (2001). Evolution and Social Anxiety: The Role of Attraction, Social Competition, and Social Hierarchies. Psychiatric Clinics, 24(4), 723-751.

DOI: https://doi.org/10.1016/S0193-953X(05)70260-4

Gurba, E. (2013). Nieporozumienia z dorastajacymi dziećmi w rodzinie. Kraków: Wydawnictwo UJ.

Guszkowska, M., Gorący, A., Rychta-Siedlecka, J. (2001). Ważne zdarzenia życiowe i codzienne kłopoty jako źródło stresu w percepcji młodzieży. Edukacja Otwarta, (4), 155-164.

Hass, R., Mann, R. (1976). Anticipatory belief change: Persuasion or impression management? Journal of Personality and Social Psychology, 34(1), 105-111. DOI: https://doi.org/10.1037/0022-3514.34.1.105 
Heszen-Niejodek, I. (2002). Emocje, ocena poznawcza i strategie w procesie radzenia sobie. W: I. Heszen-Niejodek (red.), Teoretyczne i kliniczne problemy radzenia sobie ze stresem (s. 174197). Poznań: Stowarzyszenie Psychologia i Architektura.

Jaworski, R. (2000). Konflikt pokoleń w okresie adolescencji. Psychologiczne aspekty radzenia sobie ze stresem. W: R. Jaworski, A. Wielgus, J. Łukjaniuk (red.), Problemy człowieka w świecie psychologii (s. 27-54). Płock: Wydawnictwo. Naukowe Novum.

Jelonkiewicz, I., Kosińska-Dec, K. (2008). Jasna strona stresu młodzieży (emocje pozytywne w radzeniu sobie). W: I. Heszen, J. Życińska (red.), Psychologia zdrowia. W poszukiwaniu pozytywnych inspiracji (s. 55-66). Warszawa: Wydawnictwo SWPS Academica.

Kępiński, A. (1992). Lęk. Kraków: Wydawnictwo Sagittarius.

Kłusek-Wojciszke, B. (2009). Kwestionariusz stylów rozwiązywania konfliktów. Czasopismo Psychologiczne, 15(1), 119-140.

Kobus, K., Reyes, O. (2000). A Descriptive Study of Urban Mexican American Adolescents' Perceived Stress and Coping. Hispanic Journal of Behavioral Sciences, 22(2), 163-178.

DOI: https://doi.org/10.1177/0739986300222002

Kossewska, J. (2008). Zasoby osobowe a agresja interpersonalna u młodzieży gimnazjalnej. W: H. Wrona-Polańska (red.), Zdrowie - stres - choroba w wymiarze psychologicznym (s. 145159). Kraków: Oficyna Wydawnicza Impuls.

Kowalski, K., Crocker, P., Hoar, S. (2005). Adolescent's control beliefs and doping with stress in sport. International Journal of Sport Psychology, 36(4), 257-272.

Kubacka-Jasiecka, D. (2006). Agresja i autodestrukcja z perspektywy obronno-adaptacyjnych ja. Kraków: Wydawnictwo UJ.

Lachowska, B. (2010). Style rozwiązywania konfliktów i ich efekty w relacji między rodzicami i adolescentami - prezentacja narzędzi pomiaru. W: D. Borecka-Biernat (red.), Sytuacje konfliktu w środowisku rodzinnym, szkolnym i rówieśniczym. Jak sobie radza z nimi dzieci i młodzież? (s. 180-206). Warszawa: Difin.

Lazarus, R. (1991). Emotion and Adaptation. New York: Oxford University Press.

Lazarus, R. (2000). How Emotions Influence Performance in Competitive Sports. The Sport Psychologist, 14(3), 229-252. DOI: https://doi.org/10.1123/tsp.14.3.229

Lazarus, R., Folkman, S. (1984). Stress Apprisal and Coping. New York: Springer.

Leary, M., Kowalski, R. (2001). Lęk społeczny. Gdańsk: GWP.

Lemerise, E., Dodge, K. (2005). Rozwój złości i wrogich interakcji. W: M. Lewis, J. Haviland-Jones (red.), Psychologia emocji (s. 745-760). Gdańsk: GWP.

Lohman, B., Jarvis, P. (2000). Adolescent Stressors, Coping Strategies, and Psychological Health Studied in the Family Context. Journal of Youth and Adolescence, 29, 15-43.

DOI: https://doi.org/10.1023/A:1005117020812

Łaguna, M., Bąk, W. (2007). Emocje i przekonania na temat ja. Dwa kierunki wyjaśniania ich wzajemnych relacji. W: A. Błachnio, A. Gózik (red.), Blizej emocji (s. 205-217). Lublin: Wydawnictwo KUL.

Łosiak, W. (1995). Umiejscowienie kontroli, percepcja sytuacji a lęk w sytuacji egzaminacyjnej. Rocznik Komisji Nauk Pedagogicznych, 47, 107-114.

Łosiak, W. (2009). Stres $i$ emocje $w$ naszym życiu. Warszawa: Wydawnictwa Akademickie i Profesjonalne.

Matusewicz, C. (1997). Konflikty w zespołach uczniowskich. W: W. Pomykało (red.), Encyklopedia pedagogiczna (s. 285-287). Warszawa: Fundacja Innowacja.

Mikulincer, M., Florian, V. (1995). Appraisal of and coping with real-life stressful situation: The contribution of attachment styles. Personality and Social Psychology Bulletin, 21(4), 406-415. DOI: https://doi.org/10.1177/0146167295214011

Nitendel-Bujakowa, E. (2001). Lęki szkolne jako wyznacznik funkcjonowania dziecka. Problemy Poradnictwa Psychologiczno-Pedagogicznego, (1), 15-37. 
Oleś, M. (1998). Asertywność u dzieci. Lublin: TN KUL.

Olubiński, A. (1992). Konflikty rodzice-dzieci. Dramat czy szansa. Toruń: Wydawnictwo Adam Marszałek.

Osterman, K., Bjorkqvist, K., Lagerspetz, K., Landau, S., Frączek, A., Pastorelli, C. (1997). Sex differences in styles of conflict resolution: A developmental and cross-cultural study with data from Finland, Israel, Italy and Poland. W: D. Fry, K. Bjorkqvist (eds.), Cultural Variation in Conflict Resolution: Alternatives to Violence (s. 185-197). Mahwah: Lawrence Erlbaum.

Pisula, E., Sikora, R. (2008). Wiek i płeć a radzenie sobie ze stresem przez młodzież w wieku 12-17 lat. Przeglad Psychologiczny, (4), 405-422.

Polak, K. (2010). Uczeń w sytuacji konfliktów szkolnych. W: D. Borecka-Biernat (red.), Sytuacje konfliktowe w środowisku rodzinnym, szkolnym i rówieśniczym (s. 23-40). Warszawa: Difin.

Pruitt, D., Rubin, J., Kim, S.H. (1994). Social Conflict. New York: Random House.

Ranschburg, J. (1993). Lęk, gniew, agresja. Warszawa: WSiP.

Reykowski, J. (1988). Źródła procesów ewaluatywnych i ich funkcje regulacyjne. W: B. Wojciszke (red.), Studia nad procesami wartościowania. Wrocław: Ossolineum.

Reykowski, J. (2002). Psychological meaning of democracy and resolving the social coordination problems. Polish Psychological Bulletin, (4), 19-30.

Rostowska, T. (2001). Konflikt międzypokoleniowy w rodzinie. Analiza psychologiczna. Łódź: Wydawnictwo UŁ.

Różańska-Kowal, J. (2004). Szkoła jako główne źródło stresu młodzieży w wieku dorastania. Kwartalnik Pedagogiczny, (3), 203-214.

Rubinsztejn, S. (1964). Podstawy psychologii ogólnej. Warszawa: Książka i Wiedza.

Sikorski, W. (2015). Lęk komunikacyjny u uczniów a ich sposoby reagowania w sytuacji konfliktu w klasie szkolnej. W: D. Borecka-Biernat, M. Cywińska (red.), Konflikt społeczny w perspektywie socjologicznej i pedagogiczno-psychologicznej. Wybrane kwestie (s. 126-146). Warszawa: Difin.

Spielberger, Ch.D., Starr, L. (1994). Curiosity and exploratory behavior. W: H. O’Neil Jr., D. Drillings (eds.), Motivation: Theory and Research (s. 221-243). Hillsadale: Lawrence Erlbaum Associates.

Spielberger, Ch.D., Reheiser, E. (2003). Measuring ankiet, anger, depression, and curiosity as emotional states and personality traits with the ATAI, STAXI, and STPI. W: M. Hersen, M. Hilsenroth, D. Segal (eds.), Comprehensive Handbook of Psychological Assesment (Vol. 2: Personality Assessment). Hoboken: John Wiley \& Sons.

Spielberger, Ch.D., Reheiser, E. (2009). Assessment of Emotions: Anxiety, Anger, Depression and Curiosity. Applied Psychology: Health and Well-Being, 1(3), 271-302.

DOI: https://doi.org/10.1111/j.1758-0854.2009.01017.x

Terelak, J. (2001). Psychologia stresu. Bydgoszcz: Oficyna Wydawnicza Branta.

Terry, D.J. (1994). Determinants of doping: The role of stable and situational factors. Journal of Personality and Social Psychology, 66(5), 895-910.

DOI: https://doi.org/10.1037/0022-3514.66.5.895

Tezer, E., Demir, A. (2001). Confilict behaviors toward same-sex peers among male and female late adolescents. Adolescence, 36, 525-533.

Tomaszewski, T. (1984). Ślady i wzorce. Warszawa: WSiP.

Trower, P., Gilbert, P. (1989). New theoretical conceptions of social anxiety and social phobia. Clinical Psychology Review, 9(1), 19-35. DOI: https://doi.org/10.1016/0272-7358(89)90044-5

Tyszkowa, M. (1986). Zachowanie się dzieci w sytuacjach trudnych. Warszawa: PWN.

Voss, H., Keller, H. (1983). Curiosity and Exploration. Theory and Results. San Diego: Academic Press.

Watson, D., Clark, L. (1999). Emocje, nastroje, cechy i temperament: rozważania pojęciowe i wyniki badań. W: P. Ekman, R. Davidson (red.), Natura emocji. Podstawowe zagadnienia (s. 119125). Gdańsk: GWP. 
Weeks, J., Rodebaugh, T., Heimberg, R., Norton, P., Jakatdar, T. (2009). "To Avoid Evaluation, Withdraw": Fears of Evaluation and Depressive Cognitions Lead to Social Anxiety and Submissive Withdrawal. Cognitive Therapy and Research, 33(4), 375-389.

DOI: https://doi.org/10.1007/s10608-008-9203-0

Włodarczyk, D. (1999). Rola i miejsce oceny poznawczej w radzeniu sobie ze stresem. Nowiny Psychologiczne, (4), 57-73.

Włodarczyk, D., Wrześniewski, K. (2005). Ocena stresu w kategoriach wyzwania u chorych po zawale serca - próba syntezy na podstawie danych empirycznych. Przegląd Psychologiczny, (4), 339-358.

Włodarczyk, D., Wrześniewski, K. (2010). Kwestionariusz Oceny Stresu (KOS). Przeglad Psychologiczny, (4), 479-496.

Wojciszke, B. (1988). Wpływ schematów na procesy ewaluacji. W: B. Wojciszke (red.), Studia nad procesami wartościowania (s. 54-85). Wrocław: Ossolineum.

Wojciszke, B. (2011). Psychologia społeczna. Warszawa: Wydawnictwo Naukowe Scholar.

Wright, D., London, K., Waechter, M. (2010). Social anxiety moderates memory conformity in adolescents. Applied Cognitive Psychology, 24(7), 1034-1045.

DOI: https://doi.org/10.1002/acp.1604

Wrześniewski, K. (1991). Trójczynnikowy inwentarz stanów i cech osobowości. Przegląd Lekarski, (2), 222-225.

Zimmerman, J., Morrison, A., Heimberg, R. (2015). Social anxiety, submissiveness, and shame in men and women: A moderated mediation analysis. British Journal of Clinical Psychology, 54(1), 1-15. DOI: https://doi.org/10.1111/bjc.12057

\section{SUMMARY}

The aim of the research was to study relations between cognitive evaluation of conflict and emotional reflection of the significance of this situation and the course of one's own actions as well as the occurrence of destructive (aggression, evasion, submission) and constructive (task oriented) strategy of coping with social conflict by youth. The study used the Stress Assessment Questionnaire (SAQ) by Włodarczyk and Wrześniewski, Three-Factor Inventory of Personality States and Traits (TIPST) by Spielberger and Wrześniewski, and the Questionnaire to study youths' strategies of coping in a situation of social conflict (KSMK) by Borecka-Biernat. Empirical research was conducted in secondary schools and included 893 adolescents (468 girls and 425 boys) aged 13-15. The analysis of research results demonstrates that evaluation of a conflict situation in category of threat or harm/loss and reaction to it with anger or fear co-exists with tendency to react destructively to conflict by young people. The research also demonstrated that an adolescent who has found himself in a conflict situation, and who does not evaluate the situation in terms of harm/loss and reacts with curiosity to it, will use a constructive strategy to cope with such situation.

Keywords: youth; cognitive evaluation; emotional reactions; coping strategy; social conflict situation 